\title{
Electrokinetics applied in remediation of subsurface soil contaminated with chlorinated ethenes - A review
}

Ottosen, Lisbeth M.; Larsen, Thomas H.; Jensen, Pernille Erland; Kirkelund, Gunvor Marie; KerrnJespersen, Henriette; Tuxen, Nina; Hyldegaard, Bente Højlund

\section{Published in:}

Chemosphere

Link to article, DOI:

10.1016/j.chemosphere.2019.06.075

Publication date:

2019

Document Version

Peer reviewed version

Link back to DTU Orbit

Citation (APA):

Ottosen, L. M., Larsen, T. H., Jensen, P. E., Kirkelund, G. M., Kerrn-Jespersen, H., Tuxen, N., \& Hyldegaard, B. $\mathrm{H}$. (2019). Electrokinetics applied in remediation of subsurface soil contaminated with chlorinated ethenes - A review. Chemosphere, 235, 113-125. https://doi.org/10.1016/j.chemosphere.2019.06.075

\section{General rights}

Copyright and moral rights for the publications made accessible in the public portal are retained by the authors and/or other copyright owners and it is a condition of accessing publications that users recognise and abide by the legal requirements associated with these rights.

- Users may download and print one copy of any publication from the public portal for the purpose of private study or research.

- You may not further distribute the material or use it for any profit-making activity or commercial gain

- You may freely distribute the URL identifying the publication in the public portal 


\title{
2 Electrokinetics applied in remediation of subsurface soil
}

\section{contaminated with chlorinated ethenes - A review}

\author{
Lisbeth M. Ottosen ${ }^{*}$, Thomas H. Larsen², Pernille E. Jensen ${ }^{1}$, Gunvor M. Kirkelund ${ }^{1}$, Henriette \\ Kerrn-Jespersen ${ }^{3}$, Nina Tuxen ${ }^{3}$, Bente H. Hyldegaard ${ }^{4,1}$ \\ ${ }^{1}$ Department of Civil Engineering, Building 118, Technical University of Denmark, 2800 Lyngby, Denmark \\ ${ }^{2}$ Department of Contaminated Sites \& Groundwater, Orbicon, Linnés Allé 2, 2630 Taastrup, Denmark \\ ${ }^{3}$ Centre for Regional Development, Capital Region of Denmark, Kongens Veenge 2, 3400 Hillerød, Denmark \\ ${ }^{4}$ Department of Waste \& Contaminated Sites, COWI, Parallelvej 2, 2800 Lyngby, Denmark \\ *Corresponding author.E-mail lo@byg.dtu.dk
}

\begin{abstract}
Electrokinetics is being applied in combination with common in-situ remediation technologies, e.g. permeable reactive barriers, bioremediation and in-situ chemical oxidation, to overcome experienced limitations in remediation of chlorinated ethenes in low-permeable subsurface soils. The purpose of this review is to evaluate state-of-the-art for identification of major knowledge gaps to obtain robust and successful field-implementations. Some of the major knowledge gaps include the behavior and influence of induced transient changes in soil systems, transport velocities of chlorinated ethenes, and significance of site-specific parameters on transport velocities, e.g. heterogeneous soils and hydrogeochemistry. Furthermore, the various ways of reporting voltage distribution and transport rates complicate the comparison of transport velocities across studies. It was found, that for the combined EK-techniques, it is important to control the $\mathrm{pH}$ and redox changes caused by electrolysis
\end{abstract}


for steady transport, uniform distribution of the electric field etc. Specifically for electrokinetically enhanced bioremediation, delivery of lactate and biodegrading bacteria is of the same order of magnitude. This review shows that enhancement of remediation technologies can be achieved by electrokinetics, but major knowledge gaps must be examined to mature EK as robust methods for successful remediation of chlorinated ethene contaminated sites.

\section{Key words}

Electrokinetics, chlorinated ethenes, PCE, TCE, low permeable soil, transport velosities

\section{Introduction}

Electrokinetic (EK) remediation is a group of remediation techniques utilizing the transport processes obtained when applying an electric DC field to soil. EK has the major advantage of being applicable to fine-grained soils in which other remediation techniques tend to fail. EK enables transport of ions by electromigration (EM), water by electroosmosis (EO) and charged particles by electrophoresis (EP). In recent years, research, development and implementations within EK have combined the unique EK transport processes with already practised remediation techniques to overcome the inefficiency of these latter in fine-grained soils (Lima et al., 2017).

This paper is a focused review on the results obtained with EK (from laboratory scale to full scale) in combination with other techniques for remediation of subsurface soil contaminated by chlorinated ethenes: bioremediation, in situ chemical oxidation (ISCO) and reactive barriers. The objective of the paper is to identify important knowledge and knowledge gaps in order to engineer EK in combination with other in-situ technologies for remediation of heterogeneous subsurface soils contaminated with chlorinated ethenes. 
2. Electrode reactions, potential difference and current

51

52

53

54

55

56

57

58

59

60

61

62

63

64

65

66

67

When applying an electric DC field to soil, coupled electrode reactions occur; oxidation at the anode and reduction at the cathode. In EK remediation systems, electrolysis of water most often prevails:

Anode: $\mathrm{H}_{2} \mathrm{O} \rightarrow 2 \mathrm{H}^{+}+1 / 2 \mathrm{O}_{2}(\mathrm{~g})+2 \mathrm{e}^{-}$

Cathode: $\mathrm{H}_{2} \mathrm{O}+\mathrm{e}^{-} \rightarrow \mathrm{OH}^{-}+1 / 2 \mathrm{H}_{2}(\mathrm{~g})$

Thus, around the cathode, a reducing and alkaline environment develops, whereas the environment around the anode becomes oxidized and acidic. A variety of other electrode processes may occur simultaneously depending on the applied potential, electrode material and solution chemistry. For example, when removed chloride ions reach the anode, there will be oxidization to

$\mathrm{Cl}_{2}$ from $2 \mathrm{Cl}^{-} \rightarrow \mathrm{Cl}_{2}(\mathrm{~g})+2 \mathrm{e}^{-}$

or when iron anodes are used the process, the anode corrods:

$\mathrm{Fe} \rightarrow \mathrm{Fe}^{2+}+2 \mathrm{e}^{-}$

In EK remediation, the electric DC field is applied as constant voltage (Bruell et al., 1992), (Chang et al., 2006) or constant current (Chowdhury et al., 2017b). When applying a constant current, the average charge transfer (the current) is the same in every cross section between the electrodes. When the resistivity differs over the cross-section of soil, the current will be highest in the zone with the lowest resistivity. Applying a constant voltage, on the other hand, does not necessarily result in the same potential drops $\left[\mathrm{V} \mathrm{cm}^{-1}\right]$ throughout the soil. Varying resistivities result in different potential differences. Zones with high resistivity will have a high potential drop compared to zones with a low resistivity. In experimental work with EK remediation, a constant voltage is often applied to the electrodes, which is then directly related to an average potential difference in the soil, e.g. $1 \mathrm{~V} \mathrm{~cm}^{-1}$. 
73 It must be stressed, that there can be huge variations from the average potential gradient in 74 heterogeneous soil systems, not at least because the soil conductivity will change due to geochemical changes caused by the treatment. These changes will not be equally distributed throughout the soil, and the potential differences change accordingly. A primary challenge for engineering field implementation of EK is the development of non-linear geo- and physicochemical conditions between the electrodes (Gabrieli and Alshawabkeh, 2010).

In published research on EK-remediation of chlorinated ethenes, the average potential drop in the soil is calculated directly from the applied voltage. However, a fraction of the potential drop will be at the electrodes, which should be subtracted from the applied voltage before the average voltage gradient in the soil is calculated. As the potential drop at the electrodes is often low compared to the total voltage applied, it is neglected. Ho et al. (1997) studied the relationship between applied voltage and EO in natural clay. The flow rate varied almost linearly with the applied voltage in the range of 0.1$1 \mathrm{~V} \mathrm{~cm}^{-1}$. Extrapolating the fitted line showed, that at $0.06 \mathrm{~V} \mathrm{~cm}^{-1}$, the potential gradient would be too low to drive EO. This voltage probably reflects the voltage required to drive the electrode reactions and the over-voltages associated with the particular setup (Ho et al., 1997).

When comparing transport velocities by EM, EO or EP $\left[\mathrm{cm} \mathrm{d}^{-1}\right]$, for different systems or components, it is necessary to relate the velocity to the driving force, i.e. the potential gradient $\left[\mathrm{V} \mathrm{cm}^{-1}\right]$. The transport velocity per voltage applied thus have the unit $\left[\mathrm{cm}^{2} \mathrm{~d}^{-1} \mathrm{~V}^{-1}\right]$. In this review, the potential gradient used in the calculation is the average, calculated based on the applied voltage reported. Hence, the potential differences caused by the electrode reactions are neglected.

\section{Electrokinetic transport processes}


EK-transport processes are described in this chapter together with the factors determining their velocities. The basis for EK-transport processes is charge and specifically for EP and EO that particles carry a net surface charge, which is counter-balanced by ions in the liquid phase in the very close vicinity of the particle (the electric double layer). The first layer comprises ions adsorbed onto the positively or negatively charged particle by chemical interactions. The second layer is composed of ions attracted electrostatically. This second layer is diffuse and more loosely associated with the electric attraction to the particle and thermal motion. The charge of a particle is often expressed by the zeta potential. However, in principle, the zeta potential is the potential difference between the two layers in the electrical double layer. Hence, the zeta potential is not a characteristic of the actual if the movement of the acid front is not controlled.

113 in the soil solution carry the current. Anions move towards the anode and cations towards the cathode. 
${ }^{8} \mathrm{~m}^{2} \mathrm{~V}^{-1} \mathrm{~s}^{-1}$ (Mitchell, 1991), which corresponds to $69-690 \mathrm{~cm}^{2} \mathrm{~V}^{-1} \mathrm{~d}^{-1}$. The ionic mobility of an ion relates closely to the aqueous diffusion coefficient in non-flowing systems and the dispersion tensor in flowing systems. In soils, however, the velocity is significantly lower as the ions cannot move by EM to the electrodes by the shortest route. Soil particles and air-filled voids block the direct path. The effective ionic mobility of a specific ion is a function of its molecular diffusion coefficient, soil porosity, tortuosity factor, and charge (Reddy and Cameselle, 2009). Also adsorption/desorption and precipitation/dissolution processes influence the amount and type of ions in solution under different conditions, and thereby EM of the specific ions.

The electric current is carried by ions in the electric double layer and by the ions dissolved in the pore water, which have different characteristics (Pengra and Wong, 1996). Charged porous media are filled at least by counter-ions. The dynamics of counter-ions, water molecules and co-ions depend strongly on the water content of the soil matrix. For compact matrices, the water content is low, and EM is slowed down. For less compact matrices, the dynamics of water molecules and counter-ions approach that in the bulk solution (Marry et al., 2003).

\subsection{Electrophoresis}

Charged particles will move by EP. The applied electric field, which sets the ions in the double layer in motion, acts with an electrostatic force on the particle itself due to the surface charge. The EP will be in the direction of the cathode if the particle has a net positive surface charge, and towards the anode, if the charge is negative. DeFlaun and Condee (1997) found reduced rates of transport for EP of bacteria in soils with silt and clay fractions compared to sand, indicating a major importance from the pore size on the EP mobility. The closer the particle is to a solid surface, the more profound is the boundary retarding effect, which is measured as a reduction in particle EP mobility (Tsai et al., 2011). 
Up to a $90 \%$ mobility reduction was observed when the thickness of the double layer surrounding the particle was comparable to the particle radius if the particle was sufficiently close to the solid plane. The lower the permeability of the medium, the more profound is this retarding effect (Tsai et al., 2011).

\subsection{Electroosmosis}

EO is a coupled flow (Heister et al., 2005). When the electric field is applied to soil, ions in the diffuse layer will move. Generally, the diffuse layer in soils mainly consists of cations. They are transported towards the cathode, and push and drag water molecules towards the cathode. This movement of water is EO, and the amount of water moved per ion in solution is large (Ballou, 1955).

EO is only significant in materials with fine pores due to their high relative surface charge. For example, Mikkola et al. (2008) reported insignificant EO in pure sand, whereas EO increased with increasing fraction of silt. Further, EO is most significant when the ion concentration in the pore water outside the electric double layer is low. West et al. (1999) experienced that EO in a clayey soil was significantly lower when the clay was contaminated with $\mathrm{Pb}$ above the cation exchange capacity than when below. The $\mathrm{pH}$ also influences the surface charge of the particle and hereby EO. At low $\mathrm{pH}$, the flow direction can reverse. For example, Cherepy and Wildenschild (2003) experimentally illustrated the necessity for neutralizing the $\mathrm{pH}$ changes at the electrodes to obtain steady EO. They studied a natural clayey soil in which both the EO and hydraulic conductivity decreased over time. When neutralizing the $\mathrm{pH}$ changes at the electrodes, steady EO was obtained during 31 days of testing. In this soil, the EO velocity was three orders of magnitude larger than the hydraulic velocity (Cherepy and Wildenschild, 2003). EK-remediation techniques are often targeted towards removal of 
contaminants or supply of reagents by EP, EO or EM, thus soil chemistry changes over time, thus continuously influencing EO.

\subsection{Influence from non-linear and transient changes on remediation}

The soil system changes during EK treatment and strongly influences the transport velocities. This is important to consider when designing full-scale remediation. As Reynolds et al. (2008) states, many complicating phenomena occur due to the application of an electric field, including ion diffusion, ion exchange, development of osmotic and $\mathrm{pH}$ gradients, desiccation due to heat generation at the electrodes, mineral decomposition, precipitation of salts or secondary minerals, electrolysis, hydrolysis, oxidation, reduction, physical and chemical adsorption.

Knowledge of the site-specific electrical conductivity distribution and induced changes is important to design the remediation such that the current flow where the contaminants are. The conductivity in homogeneous, inert porous materials depends on the ion concentration, composition and water content. However, soils are heterogeneous, and degradation of contaminants along with the before mentioned changes stated by Reynolds et al. (2008) will influence the electrical conductivity. The overall pattern is highly complex, partly because the changes induced by the applied electric field are transient (time and space dependent). The often non-linear response in remediation time and energy consumption required to degrade a target level of contaminants indicates the need for a site-specific approach and optimization (Wu et al., 2013). In addition, the relatively low permeability of silt and clay soils coupled with the transient and heterogeneous geochemical conditions result in transient fluid flow and development of negative or positive pore pressure (Gabrieli and Alshawabkeh, 2010), which will influence transport patterns. In summary, for the most complicated cases, concentration, 
temperature and pressure gradients are in play in addition to the applied potential gradient, i.e. all direct and coupled flows as outlined in Heister et al. (2005) are possible.

Table 2 organizes the outlined phenomena into three categories: (I) effects from applying the DC field to an inert system, (II) changes in the soil in response to the effects in (I), and (III) effects caused by the nonlinear and transient nature of the effects and changes in (I-II).

\section{Chlorinated ethene degradation pathways}

Chlorinated ethenes are subject to abiotic and biotic degradation (Vogel et al., 1987), following specific degradation pathways depending on the mechanisms involved (Figure 1). Combination of EK with other techniques induce specific degradation pathways.

\subsection{Abiotic reduction}

The abiotic reduction requires a supply of electron donors, for which zero valent metals can be applied (Roberts et al., 1996). During chemical reduction, chlorinated ethenes can concurrently follow $\beta$ elimination with the formation of chlorinated acetylenes (Figure 1, dotted arrows), and hydrogenolysis forming chlorinated intermediates or hydrocarbons (Figure 1, solid arrows) (Arnold and Roberts, 2000). For $\beta$-elimination, the formation of toxic chlorinated intermediates is bypassed and the reaction products include chloride ions $\left(\mathrm{Cl}^{-}\right)$and metal ions (Durante et al., 2013), e.g. $\mathrm{Fe}^{2+}$ when zero valent iron (ZVI) is used as a reductant. For ZVI it has been shown, that $87 \%$ of PCE, $97 \%$ of TCE, 94\% of cis-DCE, 99\% of trans-DCE follows $\beta$-elimination (Arnold and Roberts, 2000). Hence, limited formation of vinyl chloride (VC). 
215 EK has been applied to transport chlorinated ethenes towards permeable reactive barriers (PRB) in

216 low permeable soils for abiotic degradation of the contaminants. These PRBs often contain ZVI

217 (details in chapter 6). Hence, in such barriers, the degradation follows these above outlined pathways

$218 \beta$-elimination and secondary hydrogenolysis.

219

220

221

222

223

224

225

226

227

\subsection{Biotic reduction}

Generally, microbial degradation is facilitated only if the reaction can yield energy (Gibbs free-energy below 0), which is true for reduction of chlorinated ethenes and oxidation of the chlorinated intermediates. Microbial reductive dechlorination of chlorinated ethenes follows a sequence with the stepwise formation of the degradation intermediates (Figure 1, solid arrows) (Maymó-Gatell et al., 1997). Specific redox conditions are required for this reductive biodegradation to occur. The Dehalococcoides (Dhc) group of bacteria enable reductive dechlorination of tetrachloroethylene (PCE) and trichloroethylene (TCE) beyond the dichloroethylene intermediates (cis-DCE, trans-DCE, 1,1-DCE). For complete reductive dechlorination of chlorinated ethenes to the nontoxic end-product ethene, Dhc must carry a specific gene for vinyl chloride reductase (vcrA) (Lee et al., 2013; van der Zaan et al., 2010). In addition, hydrogen $\left(\mathrm{H}_{2}\right)$ must be available as an electron donor for the reduction of chlorinated solvents by $D h c$ (Fennell et al., 1997), possibly supplied by fermentation of a carbon source, e.g. lactate (Scheutz et al., 2008). The Dhc are strict anaerobes. Consequently, the surrounding environment must be sulfate reducing and/or methane forming, preferably with an oxidationreduction potential (ORP) below $-100 \mathrm{mV}$ (Kästner, 1991). Furthermore, the activity of Dhc is affected by the $\mathrm{pH}$, with $\mathrm{pH}$ 6.8-7.8 being optimum (Middeldorp et al., 1999). Dhc appear to be inhibited for $\mathrm{pH}$ below 5 and above 10, with recovered activity when favorable $\mathrm{pH}$ conditions are reestablished (Dennis et al., 2008), however, the duration of low $\mathrm{pH}$ exposure affects the ability of Dhc to recover activity at circumneutral pH (Yang et al., 2017). 
240

241

242

243

244

245

246

247

248

249

250

251

252

253

254

255

256

257

258

259

260

261

262

Application of EK enhanced bioremediation is relying on an active phase with EK applied for delivery of an electron donor and/or bacteria (potentially $D h c$ ) into the contaminated soil, followed by a passive phase of biodegradation (details in chapter 7).

\subsection{Abiotic oxidation}

Abiotic oxidation of chlorinated ethenes requires an external supply of electron acceptors. Common oxidants used include Fenton's reagent, permanganate and persulfate (Siegrist et al., 2014). The chemical oxidation of chlorinated ethenes breaks down the compounds entirely (Figure 1, dashed arrows) and thereby avoids accumulation of the reductive dechlorination intermediates. The endproducts of chemical oxidation are hydrogen $\left(\mathrm{H}^{+}\right)$, chloride ions $\left(\mathrm{Cl}^{-}\right)$, carbon dioxide $\left(\mathrm{CO}_{2}\right)$ and the reduced catalytic compound, e.g. $\mathrm{MnO}_{2}$ (s) when permanganate is used as an oxidant (Schroth et al., 2001). Thus, chemical oxidation gradually generates acidic conditions. Successful delivery of the oxidant is crucial for efficient degradation of the chlorinated ethenes.

The desire of the methods of EK-delivery of chemical oxidants (EK-ISCO) is following this outlined degradation pathway (details in chapter 8).

\section{Electrokinetic remediation of chlorinated ethene contaminated soil-overview}

Table 3 summarizes the different techniques involving EK for remediation of soils contaminated by chlorinated ethenes.

Each method is described in the following chapters along with the transport velocities related to the different techniques and a short description of the experimental data leading to the numbers. Results 
obtained in experiments using these methods, but targeting other contaminants are included in the discussion to extend the data volume for validation of e.g. EK transport velocities of bacteria. It is important to note that the transport velocities herein reported are calculated from varying fundaments reported in the literature, since there is no coherency in the way to report experimental data on transport velocities. However, the information is important as it gives the order of magnitude of the transport velocity.

\section{EK-reactive barriers. Abiotic reduction}

The general PRB concept involves emplacement of a reactive media perpendicular to the flow direction of contaminated groundwater. The contaminant plume passively migrates through the reactive media under the influence of the natural hydraulic gradient. Obiri-Nyarko et al. (2014) reviewed the general PRB technology, while Weng (2009) reviewed the combined EK-PRB technology for contaminated soil in general. When dealing with chlorinated ethenes, the contaminants are mainly transported by electrokinetics to the PRB, and if successful, the contaminants are degraded to nonhazardous compounds by abiotic reduction (Figure 1).

Another possibility for utilizing abiotic reduction in combination with EK is to transport nano-ZVI (nZVI) into the contaminated zone by EP (Pamukcu et al., 2008; Jones et al., 2011; Reddy et al., 2011; Gomes et al., 2012). However, this possibility has not yet been applied for the remediation of soil contaminated by chlorinated ethenes, and thus the transport of these contaminants towards PRBs for abiotic reduction is the principle reviewed here. As early as in the 1990s a technology named Lasagna $^{\mathrm{TM}}$ was developed based on this concept (Ho et al., 1997; Ho et al., 1999a,b). 
6.1 Transport of chlorinated ethenes by advection in an electroosmotic flow

Bruell and Segall (1992) first reported TCE removal from kaolin columns under the influence of EO. In a laboratory study on EK transport of bacteria in soils, DeFlaun and Condee (1997) observed, that TCE moved in the direction opposite to the bacteria, i.e. towards the cathode. The transport of TCE was suggested to be either due to advection in the EO flow, or that TCE is acting as a polar compound with some positive charge associated with it (DeFlaun and Condee, 1997). Chlorinated solvents can form positively charged ion pairs with protons in the dissolved phase (Chen et al., 2002). Thus, chlorinated solvents can be subject to EM (Chen et al., 2002; Mao et al., 2012). Other researchers explain the transport of TCE towards the cathode solely by advection in the EO flow (Bruell and Segall, 1992; Weng et al., 2003 ; Chang et al., 2006). Yang and Yeh (2011) reported TCE transport in an EO flow within a spiked sandy clay with accumulation in the cathode reservoir without significant TCE degradation. The EO transport rate of TCE was superior to that of PCE in a soil sampled at a contaminated site, explained by the higher water solubility of TCE (Chang et al., 2006). By relating TCE and PCE removal to changes in pore volumes by EO, they found that $85 \%$ TCE was removed after three pore volumes and 90\% PCE after five pore volumes. This difference was explained by the higher sorption of PCE to the soil.

\section{The reported velocities to reach a minimum of $70 \%$ removal of chlorinated ethenes by advection in} an EO flow are:

- Fine-grained soil: $85 \%$ TCE removal from $12 \mathrm{~cm}$ spiked fine-grained soil in 5 days under application of $1 \mathrm{~V} / \mathrm{cm}$ (Weng et al., 2003), corresponding to $2.4 \mathrm{~cm}^{2} \mathrm{~V}^{-1} \mathrm{~d}^{-1}$

- Field-sampled clay: Removal of $83-87 \%$ TCE throughout $10 \mathrm{~cm}$ spiked clay at $2 \mathrm{~V} \mathrm{~cm}^{-1}$ during 8.3 days (Chung and Lee, 2007), corresponding to a velocity of $0.6 \mathrm{~cm}^{2} \mathrm{~V}^{-1} \mathrm{~d}^{-1}$ 
- Field-sampled clayey/silty soil: At $1.2 \mathrm{~V} / \mathrm{cm}$ in 7 days, $85 \%$ removal was obtained in about 4.5 $\mathrm{cm}$ soil for PCE and $6.5 \mathrm{~cm}$ for TCE (Chang et al., 2006), corresponding to 0.5 and $0.8 \mathrm{~cm}^{2} \mathrm{~V}^{-1} \mathrm{~d}^{-}$ 1 , respectively.

- Kaolin clay: An initial TCE concentration of $150 \mathrm{mg} / \mathrm{kg}$ was reduced with $85 \% 4 \mathrm{~cm}$ into kaolinite from the anode within 5 days at $0.4 \mathrm{~V} / \mathrm{cm}$ (Bruell and Segall, 1992), corresponding to a velocity of $2 \mathrm{~cm}^{2} \mathrm{~V}^{-1} \mathrm{~d}^{-1}$

- Sandy Clay: 7 days with application of $1 \mathrm{~V} / \mathrm{cm}$ decreased the TCE concentration in a spiked sandy clay (sampled from farmland) with about $70 \%$ in the $5 \mathrm{~cm}$ closest to the anode (Yang and Yeh, 2011) This corresponds to a velocity of $0.7 \mathrm{~cm}^{2} \mathrm{~V}^{-1} \mathrm{~d}^{-1}$.

Chang and Cheng (2006) reported an improvement of PRB when combined with EK in sandy soil for degradation of PCE. However, the improvement was obtained during the first 24 hours whereafter the decrease in concentration had a similar slope as standalone EK or PRB. This reveals limited EO towards the PRB in this sandy soil and that EK only increased degradation of PCE initially in the vicinity of the PRB.

\subsection{Types and placement of PRB}

When combined with EK, different compositions and placements of the PRB have been suggested. Vertical barriers with iron filings in kaolin clay were found effective using the Lasagna ${ }^{\mathrm{TM}}$ process (Athmer and Ho, 2009). Chung and Lee (2007) used atomizing slag (PS Ball) and sand as the filter media in the PRB. Chang and Cheng (2006) found that PRB with zero valent Zn (ZVZ) performed better than ZVI for PCE degradation. 
PRB is most efficient when placed close to the anode due to the proton production aiding the reduction at the ZVI, and the acidic environment prevented the formation of iron oxides at the ZVI surfaces and thereby passivation (Chang and Cheng, 2006 ; Chen et al., 2010). The advantage of placing an anode near the PRB was also seen in relation to general PRB by Moon et al. (2005), where the contaminated groundwater moves through the PRB in a hydraulic flow; simultaneous application of ZVI and an external DC field enhanced dechlorination of TCE by 1.3-5.8 times compared to ZVI only. However, when utilizing the combined EK-PRB method in fine-grained clayey soils, the contaminants are transported by EM or advection in the EO flow towards the cathode, which suggests placing a cathode downstream the PRB.

\subsection{In situ pilot and full scale actions}

The Lasagna ${ }^{\mathrm{TM}}$ technology has been tested in-situ for treatment of clayey soil contaminated with chlorinated ethenes. The method uses DC current to heat the soil and to mobilize pore water and contaminants into the treatment zones. In the first full-scale field test, horizontal treatment zones were installed (Ho et al., 1999a). However, vertical emplacements were more practical (Athmer and Ho, 2009). With this method, no contamination is brought aboveground, since transport and destruction take place within the soil matrix (Athmer and Ho, 2004; Athmer and Ho, 2009).

Ho et al. (1999b) describe a small field test (4.6 m x $3 \mathrm{~m}$, and $4.6 \mathrm{~m}$ deep), which lasted 4 months. The purpose was to prove EO transport of TCE and to collect information for design, installation, and operation. The electrode spacing was $3 \mathrm{~m}$. In between the electrodes, three treatment zones with granular activated carbon were installed to collect and confirm transport of TCE from soil into the treatment zones. A constant current (40 A) was applied. The voltage decreased from $138 \mathrm{~V}(0.45 \mathrm{~V}$ $\left.\mathrm{cm}^{-1}\right)$ to $105 \mathrm{~V}\left(0.35 \mathrm{~V} \mathrm{~cm}^{-1}\right)$, where it stabilized. The decrease was ascribed Joule heating of the soil, 
as the temperature increased from 15 to $45{ }^{\circ} \mathrm{C}$. After plant adjustments, the EO flow rate was similar to the level obtained in the lab $\left(1.04 \mathrm{~cm}^{2} \mathrm{~V}^{-1} \mathrm{~d}^{-1}\right)$. In total, about three pore volumes were transported with EO. The highest TCE concentration before treatment was $507 \mathrm{mg} / \mathrm{kg}$ with a TCE removal of 92$99.8 \%$. About $4 \%$ of the removed TCE was volatilized. The remaining fraction of removed TCE was transported to the treatment zones where the concentration at the activated carbon reached $10,000 \mathrm{mg}$ TCE $\mathrm{kg}^{-1}$.

Ho et al. (1999a) describe a larger field scale test (6.2 m x $9.2 \mathrm{~m}$, and $13.7 \mathrm{~m}$ deep), which lasted a year. The purpose was to show effective in-situ treatment to a depth of $13.7 \mathrm{~m}$ (Athmer, 2004). The electrode spacing was $6.3 \mathrm{~m}$ and three treatment zones composed of iron fillings in kaolinite were installed in between. Each electrode comprised of a $3.8 \mathrm{~cm}$ thick layer of 50/50 iron fillings and coke to the depth of $13.7 \mathrm{~m}$. The first two months, $150 \mathrm{~V}$ was applied $\left(0.23 \mathrm{~V} \mathrm{~cm}^{-1}\right)$ corresponding to a current of 110 A. Hereafter, the voltage was increased to $200 \mathrm{~V}\left(0.31 \mathrm{~V} \mathrm{~cm}^{-1}\right)$ at $200 \mathrm{~A}$. After about 5 months, the core soil temperature was increased to $80{ }^{\circ} \mathrm{C}$ due to Joule heating, and the voltage was reduced to $120 \mathrm{~V}\left(0.19 \mathrm{~V} \mathrm{~cm}^{-1}\right)$. The voltage distribution was reasonably uniform for the first 5 months, where after the anode filling started to dry out. About 2.8 pore volumes were transported by EO. Between the treatment zones, 96-99\% TCE was removed. Between cathode and treatment zone the removal was $70 \%$ and between the anode and treatment zone, $43 \%$ was removed. The removal may be due to both evaporation and EK transport.

Athmer (2014) conducted full-scale remediation at an industrial complex, where two part-areas were remediated. The clayey soil contained aged contamination of TCE with significant levels of cis-DCE and VC. The treatment zone was installed under built infrastructure. The plant depth was $6 \mathrm{~m}$. In partarea-1, two areas were treated (33 m x $21 \mathrm{~m}$ and $20 \times 15 \mathrm{~m})$. In part-area-2, $15 \mathrm{~m}$ x $15 \mathrm{~m}$ were treated. 
Treatment zones of iron filling mixed in kaolinite slurry were placed vertically at $1.5 \mathrm{~m}$ intervals between electrodes. Reductions of TCE in part-area- 1 and part-area- 2 were estimated to $76 \%$ and $83 \%$, respectively.

These in-situ field experiences illustrate the ability of EK to mobilize chlorinated ethenes with EO in fine-grained clayey soils.

\section{EK-Bioremediation. Biotic reduction}

Bioremediation techniques broadly fall into two categories: biostimulation and bioaugmentation (Lima et al., 2017). Biostimulation is a supply of nutrients, such as electron acceptors or donors, to promote biodegradation of contaminants by indigenous microbes. Bioaugmentation is the supply of microbes possessing specific capabilities to biodegrade the targeted contaminants. The biotic degradation pathways are shown in Figure 1.

Successful bioremediation requires physical interaction between microorganisms, substrates and contaminants (Semple et al., 2004). EK transport processes can overcome the otherwise slow transport of bacteria and/or nutrients in low-permeable soils and thus improve the delivery of e.g. bacteria. Most research on EK-BIO has been on understanding and optimizing the transport processes. A review by Gill et al. (2014) examines the state of knowledge on EK-BIO and conclude that current research needs include analysis of EK-BIO in more representative environmental settings, such as those in physically heterogeneous systems in order to gain a greater understanding of the controlling mechanisms. 
405 Crucial for EK-BIO is that the applied current does not inhibit the microorganisms. When hindering 406 side effects, e.g. $\mathrm{pH}$ and redox changes, in developing inside the soil, no significant impact on the 407 microbial activity is seen (Lear et al., 2005 ; Shi et al., 2008a). Jackman et al. (1999) have shown that 408 the application of an electric DC field of $20 \mathrm{~mA} / \mathrm{cm}^{2}$ stimulates the activity of sulfur-oxidizing 409 bacteria. No research has indicated bacterial growth inhibition by the applied electric field in the 410 range used in EK remediation.

\subsection{EK-bioaugmentation}

\subsubsection{EP transport of bacteria in soil}

Bacteria have been transported by EP into sand (DeFlaun and Condee, 1997), Sandy/silty loam (DeFlaun and Condee, 1997) and field sampled clay (Wick et al., 2004; Mao et al., 2012) and bryozoan limestone (Hansen et al., 2015). EP of bacteria depends on the physico-chemical properties

417 of both the porous media (DeFlaun and Condee, 1997) and the surface properties of individual 418 bacteria (Wick et al., 2007 ; Shi et al., 2008b). Most bacterial strains carry a weak negatively charged cell surface at near neutral $\mathrm{pH}$, and thus EP is in the direction towards the anode. EP transport of bacteria in solutions is widely used within the field of micro-electrophoresis for characterization of bacteria (van der Wal et al., 1997). The surface charge of individual bacteria, expressed by the zeta potential, is inconsistent since it is influenced by the surrounding solution. The zeta potential of 423 bacteria decreases with increasing ionic strength of the solution (Zhang et al., 2015). The zeta 424 potential of three microorganisms capable of degrading chlorinated ethenes, Dhc, Geobacter and 425 Methanomethylovorans, at low ionic strength was reported to $-25 \mathrm{mV},-40 \mathrm{mV}$ and $-51 \mathrm{mV}$, 426 respectively (Zhang et al., 2015). This reveals different EP transport velocities for those 427 microorganisms since zeta potential and EP mobility are interconnected. Also, the $\mathrm{pH}$ of the soil 
solution influences the EP of bacteria. DeFlaun and Condee (1997) detected no EP transport at pH 5.5, whereas a high transport rate was seen at $\mathrm{pH} 8.5$.

Soils can restrict EP of bacteria by direct adsorption and by the pore sizes, which need to be larger than the size of the bacteria. Wick et al. (2004) showed that EP transport of weakly negatively charged and moderately adhesive cells was faster than of strongly charged and highly adhesive cells. DeFlaun and Conde (1997) reported that the presence of silt and clay minerals retarded the EP transport of bacteria. Zhang et al. (2015) reported on the microbial cell diameters: Dhc $0.62 \mu \mathrm{m}$, Geobacter 0.70 $\mu \mathrm{m}$ and Methanomethylovorans 1-1.5 $\mu \mathrm{m}$. The pore sizes vary largely in soils, but some examples give indications of the order of magnitudes: For a Brazilian soil, classified as sandy loam, $51.1 \%$ of the total porosity was in the $100-500 \mu \mathrm{m}$ size and a third of total porosity had pores $>500 \mu \mathrm{m}$ (Pieres et al., 2013). In clay, Ninjgarav et al. (2007) reported pore sizes of $0.5-1 \mu \mathrm{m}$, and in kaolinite, the pore size was less $<0.4 \mu \mathrm{m}$ (Gingine and Cardoso, 2017). Thus, in clayey soils, the diameter of bacteria and pore sizes are in the same order, suggesting a limited possibility for EP transport unless the microbial structure is flexible. Blocking of the fine pores can be a result. Without applied current, high cell concentrations affect the overall retention of cells either positively by providing more surfaces for adhesion or negatively by leaving less favorable surfaces causing blocking (Camesano and Logan, 1998). These effects might also be important when combining with EK.

\section{EP improved the transport of a TCE degrading, adhesion-deficient variant of Burkholderiucepacia} G4 (1CB) in coarse-grained sand and sandy loam (DeFlaun and Condee, 1997). EP transport velocities of $7.2-14.4 \mathrm{~cm}^{2} \mathrm{~V}^{-1} \mathrm{~d}^{-1}$ in sand and 2.4-3.6 $\mathrm{cm}^{2} \mathrm{~V}^{-1} \mathrm{~d}^{-1}$ in sandy/silty loam were observed, while the bacteria did not move without applied current. Similarly, Wick et al. (2004) found no transport of the bacteria Sphingomonas sp L138 without applied current but reached EP transport 
452

453

454

455

456

457

458

459

460

461

462

463

464

465

466

467

468

469

470

471

472

473

474

475

velocities of $5.8 \mathrm{~cm}^{2} \mathrm{~V}^{-1} \mathrm{~d}^{-1}$ in clayey soil. However, they found no EP transport of the bacteria $M$.

frederiksbergense LB501TG. The two strains have approximately the same size, but the latter is strongly adhesive, which is likely the reason for the different mobilities by EP (Wick et al., 2004).

Thus, the characteristics of the bacteria strain are of major importance to the transport by EP.

7.1.2 Transport of bacteria by advection in an electroosmotic flow

Bacteria can be transported by advection in the EO flow i.e. towards the cathode (Mao et al., 2012 ; Lee and Lee, 2001). Thus, transport of bacteria by EO is influenced by the same factors as EO (Table 1). In addition, Wick et al. (2004) reported EO transport of bacteria in soil to depend on bacteria retention by the solid phase. The transport by advection in the EO flow for Sphingomonas sp L138 and $M$. frederiksbergense $L B 501 T G$ reached velocities of $0-3.8 \mathrm{~cm}^{2} \mathrm{~V}^{-1} \mathrm{~d}^{-1}$ and $3.4-6.7 \mathrm{~cm}^{2} \mathrm{~V}^{-1} \mathrm{~d}^{-1}$ in field-sampled clayey soil, respectively (Wick et al., 2004). In another field sampled clayey soil, the vcrA copies encoded for $\mathrm{VC}$ reductase) moved at least $16 \mathrm{~cm}$ into the soil in the direction of the cathode during 56 days of applied current at the average potential gradient of $0.8 \mathrm{~V} \mathrm{~cm}^{-1}$ (Mao et al., 2012). Thus, the transport rate of $D h c$ was $16 \mathrm{~cm}$ in 47 days, corresponding to $0.4 \mathrm{~cm}^{2} \mathrm{~V}^{-1} \mathrm{~d}^{-1}$.

\subsubsection{Electrophoresis vs electroosmosis}

The transport of bacteria in soil by EP and EO are of opposite directions. The dominating mechanism depends on the bacteria, soil characteristics and soil solution chemistry. Sphingomonas sp L138 was transported in $80-90 \%$ by EO (identified by transport towards the cathode) and $10-20 \%$ by EP (transported towards the anode) (Wick et al., 2004). Mao et al. (2012) supported EO to be the major transport mechanism. In contrast, Da Rocha et al. (2009) experimentally showed that EP was the main phenomenon responsible for the transport of bacteria in clayey soil. In summary, the specific soil system and bacteria culture determine the governing EK transport mechanism. 


\subsection{EK-biostimulation}

478 Hydrogen can serve as an electron donor for biodegradation of chlorinated ethenes, and lactate is

479

480

481

497

498 499 considered one of the best hydrogen donors ( Wu et al., 2007). Lactate is tested in the literature on EK-biostimulation (alone or in combination with EK-bioaugmentation) for remediation of soil contaminated with chlorinated ethenes, and lactate is negatively charged and transported by EM towards the anode (Wu et al., 2007; Mao et al., 2012; Hansen et al., 2015). Wu et al. (2007) experienced significant EO flow in clay samples, but the opposite directed EM was still the governing transport mechanism for lactate. The EK transport of such organic additives is limited by adsorption, the natural oxygen demand and biological transformation (Wu et al., 2007). Only when the rate of injection is compatible with the rate of consumption, a homogeneous injection is possible throughout the soil (Rabbi et al., 2000). To evaluate the potential enhancement of bioremediation by injection of lactate, it is necessary to assess its reactive transport rates under the DC field (Wu et al., 2007):

- Natural clay: $4 \mathrm{~cm}^{2} \mathrm{~V}^{-1} \mathrm{~d}^{-1}$ calculated from the reported $3.2 \mathrm{~cm} \mathrm{~d}^{-1}$ and an average potential gradient of $0.8 \mathrm{~V}$ (Mao et al., 2012)

- Silty clay: $3.2 \mathrm{~cm}^{2} \mathrm{~V}^{-1} \mathrm{~d}^{-1}(\mathrm{Wu}$ et al. $2012 \mathrm{~b})$

- Clay: Lactate was detected $24 \mathrm{~cm}$ into clay towards the anode after 188 hours at $0.8 \mathrm{~V} \mathrm{~cm}^{-1}$, corresponding to $3.8 \mathrm{~cm}^{2} \mathrm{~V}^{-1} \mathrm{~d}^{-1}$ (Wu et al., 2007)

- Sand: Lactate was detected $24 \mathrm{~cm}$ into the sand towards the anode after 129 hours at $0.5 \mathrm{~V} \mathrm{~cm}^{-1}$ (Wu et al., 2007), corresponding to $8.9 \mathrm{~cm}^{2} \mathrm{~V}^{-1} \mathrm{~d}^{-1}$.

Efficient supply of lactate by EM into a $40 \mathrm{~cm}$ long silty clay spiked with PCE and anaerobic degrading bacteria (culture $\mathrm{KB} 1^{\circledR}$ ) showed full degradation to ethene whereas a reference experiment 
500

501

502

503

504

505

506

507

508

509

510

511

512

513

514

515

516

517

518

519

520

521

522

523

without application of current resulted in limited degradation (Wu et al., 2012b). Hence, if a bacteria culture capable of degrading the contaminants is present, lactate can be supplied sufficiently by EM in fine grained soils.

\subsection{Pilot scale action}

Cox et al. (2018) conducted a pilot scale action with the overall goal to demonstrate and validate EKenhanced amendment delivery for in-situ EK-BIO via enhanced reductive dechlorination of a PCE source area in clay. The EK plant consisted of 9 electrode wells and 8 supply wells located within an area of approximately $12 \times 12 \mathrm{~m}$. The depth interval targeted by the treatment was $5-7 \mathrm{~m}$. The remediation amendments distributed by EK included lactate, $\mathrm{pH}$ control reagents (potassium carbonate), and a dechlorinating microbial consortium (KB-1®) containing Dhc. The action included

2 separate stages, 5-month each, of active operation with a 6-month incubation period between the two active stages. A $>60 \%$ reduction in average PCE concentrations was achieved in soil and groundwater within the treated area. While groundwater data also showed coupled and comparable increases of dechlorination daughter (including VC) and end products, no such apparent increases of degradation products were observed in soil samples. Ethene was detected at $100 \%$ of groundwater monitoring wells and $>10 \mathrm{x}$ increases of Dhc from baseline was observed at $>60 \%$ of soil and groundwater samples collected from within the treated area.

\section{EK-ISCO. Abiotic oxidation}

In-situ chemical oxidation (ISCO) is a remediation technique where chemical oxidants are injected or mixed into the soil for rapid and complete contaminant mineralization. Most of the prevalent organic contaminants can be destroyed using catalyzed hydrogen peroxide $\left(\mathrm{H}_{2} \mathrm{O}_{2}\right)$, potassium 
permanganate $\left(\mathrm{KMnO}_{4}\right)$, activated sodium persulfate $\left(\mathrm{Na}_{2} \mathrm{~S}_{2} \mathrm{O}_{8}\right)$, ozone $\left(\mathrm{O}_{3}\right)$ or combinations of oxidants (Siegrist et al., 2014). ISCO is a promising technology, but successful delivery into low permeability zones or uniformly throughout heterogeneous zones is an unresolved challenge (Reynolds et al., 2008). To overcome this, EK-ISCO has been investigated for an optimized supply of permanganate and persulfate.

\subsection{EK-ISCO Permanganate}

Use of $\mathrm{KMnO}_{4}$ for ISCO is of significant interest due to its high oxidation-reduction potential, stability in aqueous solution, reactivity over a wide range of $\mathrm{pH}(3.5-12)$, ability to work without an activator, and production of non-toxic by-products after reaction with the chlorinated solvents (Chowdhury et al., 2017b). $\mathrm{KMnO}_{4}$ can dechlorinate chlorinated ethenes completely (Huang et al., 2001).

EK permanganate transport into homogeneous, artificial, non-contaminated soil has been investigated (Roach and Reddy, 2006; Reynolds et al., 2008; Hodges et al., 2013). In experiments without pH neutralization at the electrodes, Roach and Reddy (2006) found that EM of permanganate $\left(\mathrm{MnO}_{4}^{-}\right)$in kaolinite was limited to the proximity of the cathode due to a low $\mathrm{pH}$ in the remaining of the kaolinite. At low $\mathrm{pH}(<3.5), \mathrm{MnO}_{4}^{-}$is reduced to $\mathrm{Mn}^{2+}$, i.e. a cation, which EM towards the cathode (Roach and Reddy, 2006). In addition, the oxidation potential of $\mathrm{MnO}_{4}{ }^{-}$is lost at acidic $\mathrm{pH}$. Reynolds et al.

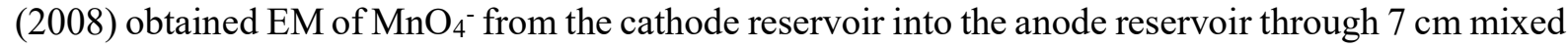
glass beads and kaolinite. In experiments with glass beads, the concentration in the anolyte relative to the catholyte was $10 \%$ with $10 \mathrm{~V}$ applied, while $15 \%$ with $20 \mathrm{~V}$ applied after 150 hours. This exceeded the $5 \%$ obtained by diffusion but lacked full break-through. In experiments with kaolinite, the concentration of $\mathrm{MnO}_{4}^{-}$in the anolyte increased with $13-15 \%$ when applying $10-20 \mathrm{~V}$ for 150 
hours. The results indicated a threshold in EM of permanganate due to competing processes or other phenomena (Reynolds et al., 2008). Hodges et al. (2013) defined those limitations as stalling. Hodges et al. (2011) developed an EK set-up in which pH changes were isolated from the soil. Using this setup, Hodges et al. (2013) showed $\mathrm{EM}$ of $\mathrm{MnO}_{4}^{-}$through a $10 \mathrm{~cm}$ long kaolinite core at neutral $\mathrm{pH}$. After 5.2 days at $1.1 \mathrm{~V} \mathrm{~cm}^{-1}, \mathrm{MnO}_{4}^{-}$was measured in the anolyte, corresponding to a transport velocity of $2.3 \mathrm{~cm}^{2} \mathrm{~V}^{-1} \mathrm{~d}^{-1}$. The concentration in the kaolinite near the anode of $1 \mathrm{~g} \mathrm{~L}^{-1}$ was the lowest inside the core. Such differences in $\mathrm{MnO}_{4}^{-}$distribution in the kaolinite is critical when considering implementation of EK-ISCO at full-scale because it can lead to inefficient contaminant degradation (Hodges et al., 2013). Thus, this needs to be overcome.

Reynolds et al. (2008) conducted experiments with fine-grained lenses of glass beads or kaolinite embedded in a non-contaminated artificial soil of coarser glass beads. The pink color of permanganate was qualitatively used to assess EM into these lenses. As opposed to when not applying an electric field, the electric field intensified the pink appearance of the lenses. Thus, EM transport from a coarse medium into a fine-porous medium was shown. Chrowdhury et al. (2017b) conducted experiments in a two-dimensional sandbox packed with layers of silt perpendicular to the electric field. The sand and silt were contaminated with aqueous TCE. EK successfully delivered $\mathrm{MnO}_{4}{ }^{-}$throughout the silt, while without $\mathrm{EK}$, the $\mathrm{MnO}_{4}^{-}$was delivered to the edges of the silt layer fringes only. TCE mass destruction in the silt could not be directly quantified, but image analysis of the silt showed a $240 \%$ increase in $\mathrm{MnO}_{4}{ }^{-}$delivery when EK was applied. Furthermore, EK-application significantly reduced the backdiffusion of TCE from the contaminated silt after active treatment for 25 days.

\subsection{EK-Persulfate}


571 Persulfate offers some advantages over the other oxidants, such as high aqueous solubility, high

572 stability in subsurfaces, lower affinity for organic matter, reduced cost, and nonhazardous end-

573 products (Matzek and Carter, 2016). Persulfate refers to ions or compounds containing the anions

$574 \mathrm{SO}_{2}{ }^{5-}$ or $\mathrm{S}_{2} \mathrm{O}_{8}{ }^{2-}$. Matzek and Carter (2016) reviewed in detail the use of activated persulfate for 575 oxidation of organics. Persulfate oxidation requires activation by either heat, mineral-based 576 activators, UV light or high pH (Matzek and Carter, 2016). Selecting the suitable activator depends 577 on site conditions such as geology, hydrogeology and the application strategy (Yukselen-Aksoy and 578 Reddy, 2012). EK assisted ISCO using persulfate is to transport the persulfate into the soil by EM or 579 EO followed by in-situ activation.

580

581 The anionic persulfate is transported by EM towards the anode or by EO towards the cathode. 582 Important findings on persulfate distribution in soil using EK can be extracted from papers on 583 laboratory work with non-contaminated soil (Mikkola et al., 2008), soil contaminated with creosote 584 (Isossari et al., 2007) or PCB (Yukselen-Aksoy and Reddy, 2012; Fan et al., 2014). EM of persulfate 585 in sand was found linearly related to the applied voltage in the range of $1-4 \mathrm{~V} \mathrm{~cm}^{-1}$ with transport rates of $12 \mathrm{~cm}^{2} \mathrm{~V}^{-1} \mathrm{~d}^{-1}$, (Mikkola et al., 2008). A tendency for higher EM velocities with increasing 587 silt content was observed, reaching $19.8 \mathrm{~cm}^{2} \mathrm{~V}^{-1} \mathrm{~d}^{-1}$ in pure silt. This was ascribed to the higher 588 electrical conductivity caused by higher water content and thus, higher current densities in the silt. 589 Chowdhury et al. (2017a) successfully delivered persulfate with EM throughout a $36 \mathrm{~cm}$ silt sample 590 at voltages of $12-18 \mathrm{~V}\left(0.5-0.8 \mathrm{~V} \mathrm{~cm}^{-1}\right)$ in a system where $\mathrm{pH}$ was controlled with phosphate buffers 591 at the electrodes. An average transport rate of $2 \pm 0.7 \mathrm{~cm} /$ day was estimated based on the arrival times 592 of $50 \%$ of the maximum persulfate concentration (Chowdhury et al., 2017a), corresponding to $3.1 \pm$ $5931.1 \mathrm{~cm}^{2} \mathrm{~V}^{-1} \mathrm{~d}^{-1}$ based on an average voltage in the range given. The persulfate concentration in the 594 soil solution reached $11 \mathrm{~g} \mathrm{~L}^{-1}$ near the cathode and $9 \mathrm{~g} \mathrm{~L}^{-1}$ near the anode. 
596 In an EK system without $\mathrm{pH}$ control, $\mathrm{EO}$ was the most efficient process for transporting persulfate 597 into a field-sampled soil (Fan et al., 2014). Persulfate was delivered $6 \mathrm{~cm}$ into the soil by EO within 598 3-6 days. Break-through of persulfate into the catholyte was not observed. On the contrary, break599 through into the anolyte with EM was observed, but here the persulfate concentration in the soil was 600 601 lower (Fan et al., 2014). Addition of persulfate from both electrodes simultaneously did not deliver persulfate uniformly (Fan et al., 2014). This work underlines the necessity to control $\mathrm{pH}$.

602

603

Injection of persulfate at the anode has shown to increase the EO flow velocity (Yang and Yeh, 2011;

604

605

606

607

608

609

610

611

612

613

614

615

616

617

618

Fan et al., 2014). Contrary, persulfate has also shown to reduce the EO flow rate significantly (Isosaari et al., 2007). Fan et al. (2016) showed that transport of persulfate by advection in an EO flow towards the cathode was influenced by the persulfate activation method used: alkaline activation $>$ zero valent iron activation $>$ no activation $>$ citric acid chelated $\mathrm{Fe}^{2+}$ activation $>$ peroxide activation $>$ iron electrode activation. Thus, the transport of persulfate by advection in EO flow depends on a variety of factors, which possibly are site-specific and thus calls for further assessment. In addition, the simultaneous addition of a suspended activator and persulfate decreased the persulfate distribution into the soil (Fan et al., 2016). Thus, adequate delivery of persulfate into the soil prior to activation is beneficial.

Efficient degradation (99\% removal) of TCE in a $25 \mathrm{~cm}$ long, spiked, field-sampled soil under an applied electric field of $1 \mathrm{~V} \mathrm{~cm}^{-1}$ during 7 days with a high dose of $10 \mathrm{~g} \mathrm{~L}^{-1}$ of Na-persulfate at the anode is observed (Yang and Yeh, 2011), corresponding to $3.6 \mathrm{~cm}^{2} \mathrm{~V}^{-1} \mathrm{~d}^{-1}$. This high removal was ascribed EO transport of $\mathrm{H}_{2} \mathrm{SO}_{5}$, which was suggested produced in the anolyte due to the strongly acidic environment. 
In a study on PCB removal, Fan et al. (2016) reported the removal efficiency order of the activation methods to be: alkaline $>$ peroxide $>$ citric acid chelated $\mathrm{Fe}^{2+}>$ Zero-valent iron $>$ no activation $>\mathrm{Fe}$ electrode activation. The removal efficiencies varied between 41 and $31 \%$. The activation methods tested and reported are: (I) Electrochemical generation of Fe(II) using an iron anode. This method was evaluated for the oxidation of phenol in a stirred solution with persulfate and phenol (Park et al., 2016). EK-transport was not included in this study, but it showed, that a continuous supply of Fe(II) from the anode was easier to control than direct addition of iron sulfate to the solution because excess

$627 \mathrm{Fe}(\mathrm{II})$ impedes the activation of persulfate. Literature available on EK- persulfate for remediation of 628 soil contaminated with chlorinated ethenes is yet scarce. (II) Thermally Activated Persulfate. 629 Temperature is a strong activator of persulfate. EK-TAP is an abbreviation for "Electrokinetic 630 Thermally Activated Persulfate", i.e. a method in the EK-ISCO family. In brief, the persulfate is 631 delivered into the soil by EK followed by a temperature increase by changing to an AC electric field 632 for electrical resistivity heating (ERH). The application of heat is expected more uniformly distributed 633 than other possible activation methods (Chowdhury et al., 2017a), and they also showed full 634 degradation of PCE in soil solution samples after two periods with persulfate supply by EM and 635 activation by ERH. Increase in sulfate concentration simultaneous to decrease in persulfate 636 concentration during ERH indicated activation and decomposition of persulfate. Activation at $36{ }^{\circ} \mathrm{C}$ 637 was more efficient in eliminating PCE than at $>41^{\circ} \mathrm{C}$. Yukselen-Aksoy and Reddy (2012) found that 638 increasing the temperature to $45^{\circ} \mathrm{C}$ was efficient for PCB degradation after EK persulfate delivery. 639 (III) Persulfate activation with ZVI and nZVI. Yang and Yeh (2011) reported that with nano-Fe the 640 TCE concentration was reduced from $132-156 \mathrm{mg} \mathrm{kg}^{-1}$ to $<10 \mathrm{mg} \mathrm{kg}^{-1}$ all through the $25 \mathrm{~cm}$ long soil 641 column, and without nano-Fe the final concentration was about 25-55 $\mathrm{mg} \mathrm{kg}^{-1} \mathrm{TCE}$ degradation in a 
642

643

644

645

646

647

648

649

650

651

652

653

654

655

656

657

658

659

660

661

662

663

664

665

spiked, field-extracted soil was app. 10-30\% more efficient when adding nZVI to the catholyte and persulfate to the anolyte than when adding persulfate alone.

Natural soil constituents influence EK-persulfate. Liang et al. (2003) showed that in aqueous systems, significant TCE degradation was obtained after 6 hours at $40{ }^{\circ} \mathrm{C}$. However, longer treatment times and higher doses of persulfate were needed for effective treatment of soil slurries, because the organic matter competed for sulfate free radicals (Liang et al., 2003). Similar, Yukselen-Aksoy and Reddy (2012) observed enhanced degradation of PCB in kaolinite than in glacial till. The difference was attributed to the high buffering capacity, nonhomogeneous mineral content and high organic content of glacial till. In general, the natural oxidant demand in soil is the reaction of permanganate with immobile, sediment-bound reductants such as organic matter, or reduced minerals such as pyrite $\left(\mathrm{FeS}_{2}\right)$ (Mumford et al., 2005). Hence, the natural oxidant demand of soil must be accounted for when dosing persulfate. Important findings on changing conditions in soil during persulfate treatment were reported by Isosaari et al. (2007). They periodically injected persulfate to a field-sampled clay and the DC field was applied from external electrodes. Phosphate buffers were added in order to control $\mathrm{pH}$ at the electrodes, but without success, i.e. $\mathrm{pH}$ changed in the injection wells throughout 8 weeks. Each injection of persulfate resulted in an increased current that leveled out over time. The authors explained the leveling out to be due to precipitation of sulfates, phosphates and hydroxides, which was verified by elemental analyses showing decreasing concentrations of $\mathrm{Al}$ and $\mathrm{Ca}$ in the soil near the anode and increasing concentrations near the cathode (Isosaari et al., 2007). P concentrations increased significantly throughout the soil originating from the buffer solutions in the electrolytes. The S concentration increased from $780 \mathrm{mg} \mathrm{kg}^{-1}$ to $1040-2980 \mathrm{mg} \mathrm{kg}^{-1}$, peaking in the soil midway between the electrodes, but whether this increase was due to the transport of persulfate or e.g. $\mathrm{SO}_{4}{ }^{2-}$ was not identified. Similarly, Fan et al. (2014) reported an initial increase in current density followed 
by a decrease during the continuous supply of persulfate by EO, also ascribed to precipitation within the soil.

The influence of common anions and cations $\left(\mathrm{CO}_{3}{ }^{2-}, \mathrm{PO}_{4}{ }^{3-}, \mathrm{HCO}_{3}{ }^{-}, \mathrm{SO}_{4}{ }^{2-}, \mathrm{NO}_{3}{ }^{-}, \mathrm{Na}^{+}, \mathrm{K}^{+}, \mathrm{Mg}^{2+}\right.$ and $\left.\mathrm{Ca}^{2+}\right)$ on the $\mathrm{Fe}^{2+}$ activated persulfate process for treatment of aniline contaminated groundwater without EK was examined by Zhao et al. (2016). Under the optimum operating conditions, 86\% aniline degradation was observed within $60 \mathrm{~min}$. The effects of the cations on aniline degradation were negligible. Anions, on the other hand, decreased the removal of aniline because of radicals generated in the reaction of sulfate radical or hydroxyl radical with these anions. The order of inhibitory effects was $\mathrm{PO}_{4}{ }^{3-}>\mathrm{CO}_{3}{ }^{2-}>>\mathrm{SO}_{4}{ }^{2-}>\mathrm{HCO}_{3}{ }^{-}>>\mathrm{NO}_{3}{ }^{-}$. The influence of anions on EKISCO of chlorinated ethenes using persulfate needs investigation in relation to EK. Especially of $\mathrm{PO}_{4}{ }^{3-}$ since the phosphate buffering system is often used to buffer $\mathrm{pH}$ at the electrodes.

\subsection{Modeling EK-ISCO}

Wu et al. (2013) took the challenge to model different electrode configurations in EK-ISCO using permanganate. The focus was to achieve optimal coverage of the oxidant. As a supplement to the previous models focusing on electrode placement during EK-remediation, e.g. Alshawabkeh et al. (1999), this model takes into account the contaminant degradation. Greater contact between the injected permanganate and PCE in the model was achieved with horizontal electrodes (Wu et al., 2013). Furthermore, reduced time for remediation can best be achieved by an increased number of electrodes, adopting bidirectional and radial electrode configurations, incorporating oxidant injection wells and a pulsed injection of oxidant (Wu et al., 2013). This will come at the cost of increased capital expenditure and in some cases, increased oxidant or energy consumption. If low-cost remediation is the objective, the electrodes should be placed further apart or fewer electrodes used, 
690

691

692

693

694

695

696

697

698

699

700

701

702

703

704

705

706

707

708

709

710

711

712

713

which results in a longer treatment time. In both cases, periodic reversal of the electric field shortened the remediation time and energy consumption (Wu et al., 2013).

\section{DISCUSSION}

\subsection{Summary of transport velocities reported}

The transport velocities calculated based on reported experimental results for chlorinated ethenes, lactate, bacteria, permanganate and persulfate are summarized in Table 4. It must be stressed, that the velocities are not directly comparable as available data differed in origin. The velocities gives the orders of magnitude. In general, reported ranges on transport velocities of chlorinated ethenes in different soil types are limited. For designing and operating in-situ full-scale remediation actions with EK-enhanced technologies, velocities are necessary design parameters, and thus must be addressed in future research.

Transport velocities of TCE and PCE by advection in the EO flow are reported in the range of 0.2$2.4 \mathrm{~cm}^{2} \mathrm{~V}^{-1} \mathrm{~d}^{-1}$ (Table 4). Thus, the velocity cannot be neglected in experimental work with all EKenhanced methods. The main purpose with EK-BIO is to extend the bioremediation to also work in fine-grained soils, and it has been shown, that bacteria are transported by EP and EO in these. The EP-transport velocities for bacteria are $0-7.2 \mathrm{~cm}^{2} \mathrm{~V}^{-1} \mathrm{~d}^{-1}$, and for advection in EO flow $0-6.7 \mathrm{~cm}^{2} \mathrm{~V}^{-1}$ $\mathrm{d}^{-1}$. EM transports lactate towards the anode and the transport velocities reported are $2.6-8.9 \mathrm{~cm}^{2} \mathrm{~V}^{-}$ ${ }^{1} \mathrm{~d}^{-1}$. Thus, lactate and bacteria are transported with velocities in the same order of magnitude. The transport velocities reported for persulfate and permanganate in EK-ISCO are $1.7-20 \mathrm{~cm}^{2} \mathrm{~V}^{-1} \mathrm{~d}^{-1}$. It has not been possible to conclude the dependency of transport velocities on soil type. Research is needed such that proper design parameters on transport velocities can be determined. 


\subsection{Importance of side effects and transient changes}

716

717

718

719

The $\mathrm{pH}$ at the electrodes must be neutralized in all the EK enhanced techniques for remediation of soil contaminated with chlorinated ethenes, since changes in soil $\mathrm{pH}$ inhibit remediation, as experienced in many of the studies reported. In EK-PRB, the changes in $\mathrm{pH}$ strongly influence EO and hereby the transport of chlorinated ethenes towards the PRB. In EK-BIO, the changes in $\mathrm{pH}$ are negatively affecting the health of the bacterial community. In EK-ISCO, $\mathrm{pH}$ influences the reactiveness and transport of the oxidants. When $\mathrm{pH}$ gradients in the soil are prevented, the changes in soil (Table 2) are less sensitive to mineral decomposition and precipitation, which thereby will contribute to a more uniform distribution of the applied electric field.

More focus needs to be given to the possible changes in soil redox conditions induced by the electrode reactions since these are important for successful remediation. The $\mathrm{O}_{2}$ containing anolyte can be transported into the soil by EO and diffusion, thus increasing the redox potential. In EK-BIO of chlorinated ethenes, the bacteria $D h c$ require strict anaerobic conditions (Section 4.2), and thus, the oxidizing conditions from the anode must be managed. For EK-ISCO, the oxidant demand must be expected to increase or the remediation efficiency to decrease if the reducing conditions from the cathode are not controlled.

Joule heating has been investigated in a few studies only (Lageman and Godschalk, 2007; Ho et al., 1997; Ho et al., 1999a), which underline the importance of coming field-scale tests with EK-BIO and EK-ISCO to include an investigation of the effect from Joule heating to take advantage of the possibly increased solubility, reaction rates and transport velocities in the field compared to lab scale. 
737 Evaporation and unwanted transport into buildings etc. need to be considered as well. Also, the energy

738 consumption required for Joule heating needs to be considered in cost calculations.

739

740

741

742

743

\subsection{EK in heterogeneous subsurface soils}

A general need for an understanding of EK in in-situ settings is stressed in recently published reviews. Research needs to include assessment of EK-technologies in more representative environmental settings, such as heterogeneous geologies, in order to I) understand the controlling mechanisms in natural settings (Gill et al., 2014), and II) be able to optimize the EK-technologies for full-scale implementation (Gomes et al., 2012). The field parameters, which influence the modelling and design of full-scale EK-remediation include heterogeneous soils in which the electrical conductivity differs in the different layers. The present review supports this. In the subsurface, the water content may change significantly, from few percentages to saturated, influencing the resistivity, pressure gradients can distribute electrolyte solutions from electrode wells into coarse, unsaturated layers and groundwater flow may counteract or enhance transport velocities, and introduce e.g. vertical flow gradients. The influence from such factors determined by the site geology has not been assessed. The robustness of the EK-methods depends on knowledge on this for sufficient engineering. Following full-scale tests, it may be necessary to step back to redesigned laboratory tests to assess knowledge gaps identified during field-tests to avoid unforeseen situations in large scale, which increase the costs significantly. Acquisition of data in the field is expensive; it is, therefore, critical to identify which processes and system parameters that ultimately determine the success of a remediation strategy (Wu et al., 2012a). For example, transport mechanisms must be fully understood to ensure unintended spreading of the contaminants is avoided. Currently, however, scarcity of data particularly on the EKparameters and at field-scale, and the related uncertainties, will affect the robustness of both modelbased predictions and designs of EK-implementations (Wu et al., 2012a). A comprehensive study, 
761

762 combined technologies is requested.

763

764

765

766

767

\section{CONCLUSIONS} complicate the comparison of studies.

which quantifies the effects of a wide range of natural and model-parameters on the efficiency of EK-

The concept of EK-enhancement of PRB, BIO and ISCO has shown encouraging results at lab-scale and for PRB and BIO also at full-scale. A major finding is that the already established methods applied in high-permeability soils can be transferred to low-permeability soils when combined with EK. This is unique and calls for a systematic approach to fill in current knowledge gaps towards safe and successful remediation. This review has identified major knowledge gaps, including transport velocities for chlorinated ethenes, changes in redox conditions in different soils due to electrode reactions, significance of the advantageous Joule heating for reaction rates, transport velocities and bacteria activity, and significance of site-specific parameters on transport velocities, e.g. heterogeneous geology and thereby electrical conductivities, water content, pressure gradients, hydrology, hydrogeochemistry, and oxygen demand and buffering capacity of the soil. In addition, there is a lack of coherence on how to report data on voltage distribution and transport rates, which

In this review, it was found, that for the combined EK-techniques, it is necessary to manage the induced changes in $\mathrm{pH}$ to obtain steady EO transport of chlorinated ethenes, EP of bacteria, a healthy bacteria community, uniform delivery and reactivity of oxidants, and to control mineral decomposition and precipitation for a uniformly distributed electric field. Calculated transport velocities based on reported data show, that for EK-BIO, EM of lactate and EP of the biodegrading bacteria are in the same order of magnitude. When applying EK-techniques, back-diffusion of 
contaminants from low-permeable soils is lowered, and periodic reversal of the electric field appears to shorten the remediation time and energy consumption.

This review underlines the promising use of EK for enhancement of remediation technologies, but it also highlights some major knowledge gaps that must be understood for the EK-techniques to be optimized and become robust enough for successful field-implementation at different sites with heterogeneous subsurface.

\section{ACKNOWLEDGEMENTS}

The work was funded by the Capital Region of Denmark

\section{REFERENCES}

Alshawabkeh, A., Yeung, A.T., Bricka, M.R., 1999. Practical aspects of in-situ electrokinetic extraction. J. Environ. Eng. 125, 27-35.

Athmer, C.J., 2004. In-situ remediation of TCE in clayey soils. Soil and sediment cvogeontamination 13, 381-390.

Athmer, C.J., 2014. Use of large-scale electrokinetic and ZVI treatment for chlorinated solvent remediation at an active industrial facility. Remediation $24,41-51$.

Athmer, C., Ho, S.V, 2009. Field studies: organic - contaminated soil remediation with lasagna technology. In: Reddy, K.R., Cameselle, C. (Eds.), Electrochemical Remediation Technologies for Polluted Soils, Sediments and Groundwater. John Wiley \& Sons, Inc., Hobroken, New Jersey, 625-646.

Ballou, E.V. 1955. Electroosmotic flow in homogenic kaolinite. J. Colloid Science 10(5), 450-460.

Bruell, C.J., Segall, B.A., Walsh, M.T., 1992. Electroosmotic removal of gasoline hydrocarbons and 
TCE from clay. J. Environ. Eng. 118, 68-83.

808

809

810

811

812

813

814

815

816

817

818

819

820

821

822

823

824

825

826

827

Camesano, T.A., Logan, B.E., 1998. Influence of fluid velocity and cell concentration on the transport of motile and nonmotile bacteria in porous media. Environ. Sci. Technol. 32, 16991708.

Chang, J.H., Cheng, S.-F., 2006. The remediation performance of a specific electrokinetics integrated with zero-valent metals for perchloroethylene contaminated soils. J Hazard. Mater. B131, 153-162.

Chang, J.-H., Qiang, Z., Huang, C.-P., 2006. Remediation and stimulation of selected chlorinated organic solvents in unsaturated soil by a specific enhanced electrokinetics. Colloids Surf. A Physicochem. Eng. Asp. 287, 86-93.

Chen, S.S., Huang, Y.-C., Kuo, T.-Y., 2010. The remediation of perchloroethylene contaminated groundwater by nanoscale iron reactive barrier integrated with surfactant and electrokinetics. Ground Water Monit. Remediat. 30, 90-98.

Cherepy, N.J., Wildenschild, D., 2003. Electrolyte management for effective long-term electroosmotic transport in low-permeability soils. Environ. Sci. Technol. 37, 3024-3030.

Chowdhury, A.I.A., Gerhard, J.I., Reynolds, D., O’Carroll, D.M., 2017a. Low permeability zone remediation via oxidant delivered by electrokinetics and activated by electrical resistance heating: Proof of concept. Environ. Sci. Technol. 51, 13295-13303.

Chowdhury, A.I.A., Gerhard, J.I., Reynolds, D., Sleep, B.E., O'Carroll, D.M., 2017 b. Electrokinetic-enhanced permanganate delivery and remediation of contaminated low permeability porous media. Water Res. 113, 215-222. 
Cox, E., Gent, D., Singletary, M., Wilson, A., 2018. Electrokinetic-enhanced (EK-enhanced) amendment delivery for remediation of low permeability and heterogeneous materials. Department of Defense Environmental Security Technology Certification Program (ESTCP) Project ER-201325

Da Rocha, U.N., Tótola, M.R., Pessoa, D.M.M., Júnior, J.T.A., Neves, J.C.L., Borges, A.C., 2009. Mobilisation of bacteria in a fine-grained residual soil by electrophoresis. J Hazard. Mater. $161,485-491$.

DeFlaun, M.F., Condee, C.W., 1997. Electrokinetic transport of bacteria. J Hazard. Mater. 55, 263277.

Fan, G., Cang, L., Fang, G., Qin, W., Ge, L., Zhou, D., 2014. Electrokinetic delivery of persulfate to remediate PCBs polluted soils: Effect of injection spot. Chemosphere 117, 410-418.

Fan, G., Cang, L., Gomes, H., Zhou, D., 2016. Electrokinetic delivery of persulfate to remediate PCBs polluted soils: Effect of different activation methods. Chemosphere 144, 138-147.

Fennell, D.E., Gossett, J.M., Zinder, S.H., 1997. Comparison of butyric acid, ethanol, lactic acid, and propionic acid as hydrogen donors for the reductive dechlorination of tetrachloroethene. Environ. Sci. Technol. 31, 918-926.

Gabrieli, L., Alshawabkeh, A.N., 2010. Influence of boundary conditions on transient excess pore pressure during electrokinetic applications in soils. J. Appl. Electrochem. 40, 1113-1121.

Gingine, V., Cardoso, R., 2017. Secondary consolidation of a consolidated kaolin slurry during electrokinetic treatment. Eng. Geol. 220, 31-42.

Gill, R.T., Harbottle, M.J., Smith, J.W.N., Thornton, S.F., 2014. Electrokinetic-enhanced bioremediation of organic contaminants: A review of processes and environmental 
applications. Chemosphere 107, 31-42.

Gomes, H.I., Dias-Ferreira, C., Ribeiro, A.B., 2012. Review. Electrokinetic remediation of organochlorides in soil: Enhancement techniques and integration with other remediation technologies. Chemosphere 87, 1077-1090.

Gomes, H.I., Dias-Ferreira, C., Ribeiro, A.B., Pamukcu, S., 2012.Electrokinetic Enhanced Transport of zero valent iron nanoparticles for chromium(VI) reduction in Soils. Chem. Eng. Trans. 28, 139-144.

Hansen, B.H., Nedergaard, L.W., Ottosen, L.M., Riis, C., Broholm, M.M., 2015. Experimental design for assessment of electrokinetically enhanced delivery of lactate and bacteria in 1,2-cisdichloroethylene contaminated limestone. Environ. Technol. Innov. 4, 73-81.

Heister, K., Kleingeld, P.J., Keijzer, T.J.S., Loch J.P.G., 2005. A new laboratory set-up for measurements of electrical, hydraulic, and osmotic fluxes in clays. Eng. Geol. 77, 295-303.

Ho, S.V., Athmer, C., Sheridan, P.W., Shapiro, A., 1997. Scale-up aspects of the Lasagna ${ }^{\mathrm{TM}}$ process for in situ soil decontamination. J Hazard. Mater. 55, 39-60.

Ho, S.V., Athmer, C., Sheridan, P.W., Hughes, B.M., Orth, R., McKensie, D., Brodsky, P.H., Shapiro, A., Sivavec, T.M., Salvo, J., Schultz, D., Landis, R., Griffith, R., Shoemaker, S., 1999a. The Lasagna Technology for in situ soil remediation 1. Large field test. Environ. Sci. Technol. 33, 1092-1099.

Ho, S.V., Athmer, C., Sheridan, P.W., Hughes, B.M., Orth, R., McKensie, D., Brodsky, P.H., Shapiro, A., Thornton, R., Salvo, J., Schults, D., Landis, R., Griffith, R., Shoemaker, S., 1999b. The Lasagna Technology for in situ soil remediation 1. Small field test. Environ. Sci. Technol. 33, 1086-1091. 
872 Hodges, D., Fouire, A., Reynolds, D., Thomas, D., 2011. Development of an apparatus for pH-

873 isolated electrokinetic in situ chemical oxidation. J. Environ. Eng. 137, 809-816.

874 Hodges, D., Fouire, A., Thomas, D., Reynolds, D., 2013. Overcoming permanganate stalling during 875 electromigration. J. Environ. Eng. 139, 677-684.

876 Huang, K.-C., Hoag, G.E., Chheda, P., Woody, B.A., Dobbs, G.M., 2001. Oxidation of chlorinated 877 ethenes by potassium permanganate: a kinetics study. J Hazard. Mater. B87, 155-169.

878 Isosaari, P., Piskonen, R., Ojala, P., Voipio, S., Eilola, K., Lehmus, E., Itävaara, M., 2007.

879 Integration of electrokinetics and chemical oxidation for the remediation of creosote$880 \quad$ contaminated clay. J Hazard. Mater. 144, 538-548.

881 Jackman, S.A., Maini, G., Sharman, A.K., Knowles, C.J., 1999. The effects of direct electric current 882 on the viability and metabolism of acidophilic bacteria. Enzyme. Microb. Tech. 24, 316-324.

883 Jones, E.H., Reynolds, D.A., Wood, A.L., Thomas, D.G., 2011. Use of electrophoresis for $884 \quad$ transporting nano-iron in porous media. Groundwater 49, 172-183.

885

886

887

Lageman, R., Godschalk, M.S., 2007. Electro-bioreclamation. A combination of in situ remediation techniques proves successful at a site in Zeist, the Netherlands. Electrochim. Acta 52, 34493453.

Lear, G., Harbottle, M.J., van der Gast, C.J., Jackman, S.A., Knowles C.J., Sills, G., Thompson, I.P., 2005. The effect of electrokinetics on soil microbial communities. Soil. Biol. Biochem. $36,1751-1760$.

Lee, P.K.H., Cheng, D., West, K.A., Alvarez-Cohen, L. He, J., 2013. Isolation of two new Dehalococcoides mecartyi strains with dissimilar dechlorination functions and their characterization by comparative genomics via microarray analysis. Environ. Microbiol. 15, 
895

896

897

898

899

900

901

902

903

904

905

906

907

908

909

910

911

912

913

914

915

Lee, H.-S., Lee, K., 2001. Bioremediation of diesel-contaminated soil by bacterial cells transported by electrokinetics. J Microbiol. Biotechn. 11, 1038-1045.

Liang, C.J., Bruell, C.J., Marley, M.C., Sperry, K.L., 2003. Thermally activated persulfate oxidation of trichloroethylene (TCE) and 1,1,1-trichloroethane (TCA) in aqueous systems and soil slurries. Soil Sediment. Contam. 12, 207-228.

Lima, A.T., Hofmann, A., Reynolds, D.R., Ptacek, C.J., Van Cappellen, P., Ottosen, L.M., Pamukcu, S., Alshawabekh, A., O'Carroll, D.M., Riis, C., Cox, E., Gent, D.B., Landis, R., Wang, J., Chowdhury, A.I.A., Secord, E.L., Sanchez-Hachair, A., 2017. Environmental Electrokinetics for a sustainable subsurface. Chemosphere 181, 122-133.

Matzek, L.W., Carter, K.E., 2016. Activated persulfate for organic chemical degradation: A review. Chemosphere 151, 178-188.

Mao, X., Wang, J., Ciblaka, A., Cox, E.E., Riis, C., Terkelsen, M., Gent, D.B., Alshawabkeh, A.N., 2012. Electrokinetic-enhanced bioaugmentation for remediation of chlorinated solvents contaminated clay. J Hazard. Mater. 213-214, 311-317.

Marry, V., Dufreche, J.F., Jardat, M., Meriguet, G., Turq, P., Grun, F., 2003. Dynamics and transport in charged porous media. Colloid Surf. A Physicochem. Eng. Asp. 222, 147-153.

Maymó-Gatell, X., Chien, Y.T., Gossett, J.M., Zinder, S.H., 1997. Isolation of a bacterium that reductively dechlorinates tetrachloroethene to ethene. Science 276, 1568-1571.

Mikkola, H., Schmale, J.Y., Wesner, W., Petkovska, S., 2008. Laboratory pre-assays for soil remediation by electro synthesis of oxidants and their electrokinetic distribution. J. Environ. Sci. Health A 43, 907-912. 
Mitchell, J.K. Fundamentals of soil behavior. $2^{\text {nd }}$ edition, John Wiley \& Sons, New York, USA, 1993

Moon, J.-W., Moon, H.-S., Kim, H., Roh, Y., 2005. Remediation of TCE-contaminated groundwater using zero valent iron and direct current: experimental results and electron competition model. J. Environ. Geol. 48, 805-817.

Mumford, K.G., Thomson, N.R., Allen-King, R.M., 2005. Bench-scale investigation of permanganate natural oxidant demand kinetics. Environ. Sci. Technol. 39, 2835-2840.

Ninjgarav, E., Chung, S.-G., Jang, W.-Y., Ryu, C.-K., 2007. Pore size distribution of Pusan clay measured by mercury intrusion porosimetry. Ksce J. Civil Eng. 11, 133-139.

Obiri-Nyarko, F., Grajales-Mesa, S.J., Malina, G., 2014. An overview of permeable reactive barriers for in situ sustainable groundwater remediation. Chemosphere 111, 243-259.

Pamukcu S., Hannum L., Wittle J.K., 2008. Delivery and activation of nano-iron by DC electric field, J. Environ. Sci. Health A 43, 934-944.

Park, S.-M., Lee, S.-W., Jeon, P.-Y., Baek, K., 2016. Iron Anode-Mediated Activation of Persulfate. Water Air Soil Pollut. 227, 462.

Pengra, D.B., Wong, P.Z., 1996. Electrokinetic phenomena in porous media. Mater. Res. Soc. Symp. P. 407, 3-14.

Rabbi, M., Clark, B., Gale, R.J., Ozsu-Acar, E., Pardue, J., Jackson, A., 2000. In situ TCE bioremediation study using electrokinetic cometabolite injection. Waste Manage. 20, 279286. 
Reddy, K.R., Cameselle, C., 2009. Overview of electrochemical remediation technologies, In Electrochemical remediation technologies for polluted soils, sediments and groundwater, Eds. Reddy, K.R. \& Cameselle, C. John Wiley \& Sons, Inc., 3-28.

Reddy K.R., Darko-Kagy K., Cameselle C., 2011. Electrokinetic-enhanced transport of lactatemodified nanoscale iron particles for degradation of dinitrotoluene in clayey soils, Sep. Purif. Technol. 79, 230-237.

Reynolds, D.A., Jones, E.H., Gillen M., Yusoff, I., Thomas, D.G., 2008. Electrokinetic migration of permanganate through low-permeability media. Ground Water 46, 629-637.

Roach, N., Reddy, K.R., 2006. Electrokinetic delivery of permanganate into low-permeable soils. International Journal of Environment and Waste Manage. 1, 4-19.

Semple, K.T., Doick, K.J., Jones, K.C., Burauel, P., Craven, A., Harms, H., 2004. Defining bioavailability and bioaccessibility of contaminated soil and sediment is complicated. Environ. Sci. Technol. 38, 228A-231A.

Shi, L., Mueller, S., Harms, H., Wick, L.Y., 2008a. Effect of electrokinetic transport on the vulnerability of PAH-degrading bacteria in a model aquifer. Environ. Geochem. Hlth. 30, $177-182$.

Shi, L., Mueller, S., Harms, H., Wick, L.Y., 2008b. Factors influencing the electrokinetic dispersion of PAH-degrading bacteria in a laboratory model aquifer. Appl. Microbiol. Biotechnol. 80, $507-515$.

Siegrist, R.L., Crimi, M., Thomson, N. R., Clayton, W.S., Marley, M.C., 2014. In situ chemical oxidation. In Chlorinated Solvent Source Zone Remediation (Eds Kueper, B.H., Stroo, H.F., Vogel, C.M., Ward, C.H.). Serdp/estcp Environmental Remediation Technology book series 7, 
959

960

961

962

963

964

965

966

967

968

969

970

971

972

973

974

975

976

977

978

Tsai, P, Huang, C.-H., Lee, E., 2011. Electrophoresis of a charged colloidal particle in porous media: Boundary effect of a solid plane. Langmuir 27, 13481-13488.

van der Wal, A., Minor, M., Norde, W., Zehnder, A.J.B., Lyklema, J.,1997. Electrokinetic potential of bacterial cells. Langmuir 13, 165-171.

van der Zaan, B., Hannes, F., Hoekstra, N., Rijnaarts, H., de Vos, V.M., Smidt, H., Gerritse., J., 2010. Correlation of Dehalococcoides 16S rRNA and Chloroethene-Reductive Dehalogenase Genes with Geochemical Conditions in Chloroethene-Contaminated Groundwater. Appl. Environ. Microbiol. 76, 843-850.

Vogel, T.M., Criddle, C.S., McCarty, P.L., 1987. ES Critical Reviews: Transformations of halogenated aliphatic compounds. Environ. Sci. Technol. 21, 722-36.

Weng, C.H., 2009. Coupled electrokinetic-permeable reactive barriers. In: Reddy, K.R., Cameselle, C. (Eds.), Electrochemical Remediation Technologies for Polluted Soils, Sediments and Groundwater. John Wiley \& Sons, Inc., Hobroken, New Jersey, 483-504.

Weng, C.-H., Yuan, C., Tu, H.-H., 2003. Removal of trichloroethylene from clay soil by serieselectrokinetic process. Practice Periodical of Hazardous, Toxic, and Radioactive Waste Management 7, 25-30.

West, L.J., Stewart, D.I., Binley, A.M., Shaw, B., 1999. Resistivity imaging of soil during electrokinetic transport. Eng. Geol. 53, 205-215.

Wick, L.Y., Mattle, P.A., Wattiau, P., Harms, H., 2004. Electrokinetic Transport of PAH-Degrading Bacteria in Model Aquifers and Soil. Environ. Sci. Technol. 38, 4596-4602. 
Wick, L.Y., Shi, L., Harms, H., 2007. Electro-bioremediation of hydrophobic organic soilcontaminants: A review of fundamental interactions. Electrochim. Acta 52, 3441-3448.

Wu, M.Z., Reynolds, D.A., Fourie, A., Thomas D.G., 2013. Optimal field approaches for electrokinetic in situ oxidation remediation. Ground Water Monit. Remediat. 33, 62-74.

Wu, M.Z., Reynolds, D., Fourie, A., Prommer, H., Thomas, D.G., 2012a. Electrokinetic in situ oxidation remediation: Assessment of parameter sensitivities and the influence of aquifer heterogeneity on remediation efficiency. J. Contam. Hydrol. 136, 72-85.

Wu, X., Gent, D.B., Davis, J.L., Alshawabkeh, A.N., 2012b. Lactate injection by electric currents for bioremediation of tetrachloroethylene in clay. Electrochim. Acta 86, 157-163.

Wu, X., Alshawabkeh, A.N., Gent, D.B., Larson, S.L., Davis, J.L., 2007. Lactate transport in soil by DC fields. J. Geotech. Geoenviron. 133, 1587-1596.

Zhang, H., Ulrich, A.C., Liu, Y., 2015. Retention and transport of an anaerobic trichloroethene dechlorinating microbial culture in anaerobic porous media. Colloid. Surface. B. 130, 110118.

Zhao, Y., Zhao, Y., Li, Q., Zhou, R., Chen, X., 2016. Effect of common inorganic ions on aniline degradation in groundwater by activated persulfate with ferrous iron. Wa. Sci. Technol. 16, 667-674.

Yang, Y., Capiro, N.L., Yan, J., Marcet, T.F., Pennell, K.D., Loffler, F.E., 2017. Resilience and recovery of Dehalococcoides mccartyi following low $\mathrm{pH}$ exposure. FEMS Microbiol. Ecol. 93, fix130 (1-9)

Yang, G.C.C., Yeh, C.-F., 2011. Enhanced nano- $\mathrm{Fe}_{3} \mathrm{O}_{4} / \mathrm{S}_{2} \mathrm{O}_{8}{ }^{2-}$ oxidation of trichloroethylene in a clayey soil by electrokinetics. Sep. Purif. Technol. 79, 264-271. 
1001 Yukselen-Aksoy,Y., Reddy, K.R., 2012 Effect of soil composition on electrokinetically enhanced 1002 persulfate oxidation of polychlorobiphenyls. Electrochim. Acta 86, 164- 169.

1003 


\begin{tabular}{lll}
\hline Transport process & Transport of: & Transport velocity depends on: \\
\hline Electromigration (EM) & Ions & Ionic mobility, adsorption/desorption, precipitation/dissolution, \\
& & water content, pore volume and geometry \\
\hline Electrophoresis (EP) & Particles, colloids, & Soil zeta potential, pore water chemistry and conductivity, pore \\
& bacteria & sizes, water content \\
\hline Electroosmosis (EO) & Water & Soil zeta potential, pore water chemistry and conductivity \\
\hline
\end{tabular}

1005

1006 Table 1: Soil characteristics and reactions in soil systems influencing electromigration, electrophoresis and 1007 electroosmosis in the electric field 


\begin{tabular}{lll}
\hline I. Effects from applying DC field to & II. Changes in soil & III. Transient changes \\
an inert system & & \\
\hline Transport processes & Mineral decomposition & Non-uniform current and voltage \\
Electromigration & Precipitation/dissolution of salts & distribution \\
Electroosmosis & Precipitation/dissolution of secondary & Concentration gradients \\
Electrophoresis & minerals & Pore pressure (negative or positive) \\
& Physical and chemical & Temperature gradient \\
At electrodes & adsorption/desorption & pH and redox gradients \\
Anode: Oxidation and $\mathrm{pH}$ decrease & Ion exchange & \\
Cathode: Reduction and $\mathrm{pH}$ increase & Joule heating & \\
& pH and redox changes & \\
\hline
\end{tabular}




\begin{tabular}{|c|c|c|c|c|}
\hline Method & $\begin{array}{l}\text { Remediation } \\
\text { strategy }\end{array}$ & $\begin{array}{l}\text { Substance } \\
\text { transported by } \\
\text { EK }\end{array}$ & $\begin{array}{l}\text { Transport } \\
\text { process }\end{array}$ & References \\
\hline EK-PRB & $\begin{array}{l}\text { Transport to } \\
\text { treatment } \\
\text { zone with } \\
\text { abiotic } \\
\text { reduction }\end{array}$ & $\begin{array}{l}\text { Chlorinated } \\
\text { ethenes }\end{array}$ & Electroosmosis & $\begin{array}{l}\text { Bruell et al. (1992), Ho et al. } \\
\text { (1997), Ho et al. (1999b), Ho et } \\
\text { al. (1999a), Weng et al. (2003), } \\
\text { Athmer (2004), Chang et al. } \\
\text { (2006), Athmer \& Ho (2009), } \\
\text { Athmer (2014) }\end{array}$ \\
\hline \multirow[t]{3}{*}{ EK-BIO } & $\begin{array}{l}\text { In situ biotic } \\
\text { reduction }\end{array}$ & Bacteria & $\begin{array}{l}\text { Electrophoresis } \\
\text { and/or } \\
\text { electroosmosis }\end{array}$ & DeFlaun \& Condee (1997) \\
\hline & & Substrate & Electromigration & $\begin{array}{l}\text { Rabbi et al. (2000), Wu et al } \\
(2007), \text { Wu et al. (2012b) }\end{array}$ \\
\hline & & $\begin{array}{l}\text { Substrate and } \\
\text { bacteria }\end{array}$ & $\begin{array}{l}\text { Electromigration, } \\
\text { electrophoresis } \\
\text { and/or } \\
\text { electroosmosis }\end{array}$ & $\begin{array}{l}\text { Mao et al. (2012), Hansen et al. } \\
\text { (2015) }\end{array}$ \\
\hline \multirow[t]{2}{*}{ EK-ISCO } & In situ & Permanganate & Electromigration & Chowdhury et al. (2017b) \\
\hline & $\begin{array}{l}\text { abiotic } \\
\text { oxidation }\end{array}$ & Persulfate & Electromigration & $\begin{array}{l}\text { Yang \& Yeh (2011), Chowdhury } \\
\text { et al. (2017a) }\end{array}$ \\
\hline
\end{tabular}

1013

Table 3: Methods involving EK for remediation of soils contaminated with chlorinated ethenes, including substances 


\begin{tabular}{|c|c|c|c|c|c|c|c|}
\hline Method & $\begin{array}{l}\text { Transported } \\
\text { specie }\end{array}$ & $\begin{array}{l}\text { Transport } \\
\text { process }\end{array}$ & Soil & $\begin{array}{l}\text { Voltage } \\
\text { applied } \\
{\left[\mathrm{V} \mathrm{cm}^{-1}\right]}\end{array}$ & $\begin{array}{l}\text { Transport } \\
\text { rate } \\
{\left[\mathrm{cm} \mathrm{d}^{-1}\right]}\end{array}$ & $\begin{array}{l}\text { Velocity } \\
{\left[\mathrm{cm}^{2} \mathrm{~V}^{-1} \mathbf{d}^{-1}\right]}\end{array}$ & References \\
\hline \multirow[t]{5}{*}{ EK-PRB } & TCE & EO/EM & $\begin{array}{l}\text { Field-sampled clay } \\
\left(\mathrm{d}_{50}=28 \mu \mathrm{m}, \mathrm{OM}\right. \\
1.8 \%) \text {, spiked }\end{array}$ & 1.0 & 2.4 & 2.4 & $\begin{array}{l}\text { Weng et al. } \\
\text { (2003) }\end{array}$ \\
\hline & TCE & EO/EM & $\begin{array}{l}\text { Field-sampled clay } \\
\text { (Particles }<75 \mu \mathrm{m} \\
\text { 90\%, OM 6.7\%), } \\
\text { spiked }\end{array}$ & 2.0 & 1.2 & 0.6 & $\begin{array}{l}\text { Chung \& } \\
\text { Lee (2007) }\end{array}$ \\
\hline & PCE & EO/EM & $\begin{array}{l}\text { Field-sampled (48\% } \\
\text { clay, OM 1.7\%/), } \\
\text { spiked }\end{array}$ & 2.7 & 0.6 & 0.2 & $\begin{array}{l}\text { Chang et } \\
\text { al. (2006) }\end{array}$ \\
\hline & TCE & EO/EM & $\begin{array}{l}\text { Field-sampled (48\% } \\
\text { clay, OM 1.7\%/), } \\
\text { spiked }\end{array}$ & 1.8 & 0.9 & 0.5 & $\begin{array}{l}\text { Chang et } \\
\text { al. (2006) }\end{array}$ \\
\hline & TCE & EO/EM & Kaolinite, spiked & 0.4 & 0.8 & 2 & $\begin{array}{l}\text { Bruell \& } \\
\text { Segall } \\
\text { (1992) }\end{array}$ \\
\hline \multirow[t]{3}{*}{ EK-BIO } & Lactate & EM & $\begin{array}{l}\text { Field-samled low- } \\
\text { plasticity silty clay, } \\
\text { non-contaminated }\end{array}$ & 0.8 & 3.1 & 3.8 & $\begin{array}{l}\text { Wu et al. } \\
\text { (2007) }\end{array}$ \\
\hline & Lactate & EM & $\begin{array}{l}\text { Fine grained sand, } \\
\text { non-contaminated }\end{array}$ & 0.5 & 4.5 & 8.9 & $\begin{array}{l}\text { Wu et al. } \\
\text { (2007) }\end{array}$ \\
\hline & Lactate & EM & $\begin{array}{l}\text { Field-sampled clay } \\
(<10 \% \text { sand), aged } \\
\text { contamination }\end{array}$ & 0.8 & 3.2 & 2.6 & $\begin{array}{l}\text { Mao et al. } \\
\text { (2012) }\end{array}$ \\
\hline
\end{tabular}




\begin{tabular}{|c|c|c|c|c|c|c|}
\hline $\begin{array}{l}\text { Burkholderiu } \\
\text { cepacia G4 } \\
(1 C B)\end{array}$ & EP & $\begin{array}{l}\text { Coarse-grained sand, } \\
(\sim 750 \mu \mathrm{m}), \text { non- } \\
\text { contaminated }\end{array}$ & 10 & 72 & 7.2 & $\begin{array}{l}\text { DeFlaun \& } \\
\text { Condee } \\
\text { (1997) }\end{array}$ \\
\hline $\begin{array}{l}\text { Burkholderiu } \\
\text { cepacia G4 } \\
(1 C B)\end{array}$ & EP & $\begin{array}{l}\text { Fine-grained sand, } \\
(70-350 \mu \mathrm{m}), \text { non- } \\
\text { contaminated }\end{array}$ & 10 & 72 & 14.4 & $\begin{array}{l}\text { DeFlaun \& } \\
\text { Condee } \\
\text { (1997) }\end{array}$ \\
\hline $\begin{array}{l}\text { Burkholderiu } \\
\text { cepacia G4 } \\
(1 C B)\end{array}$ & EP & $\begin{array}{l}\text { Sandy loam }(14 \% \\
\text { clay, } 1.4 \% \mathrm{OM}) \text {, non- } \\
\text { contaminated }\end{array}$ & 10 & 36 & 3.6 & $\begin{array}{l}\text { DeFlaun \& } \\
\text { Condee } \\
\text { (1997) }\end{array}$ \\
\hline $\begin{array}{l}\text { Burkholderiu } \\
\text { cepacia G4 } \\
(1 C B)\end{array}$ & EP & $\begin{array}{l}\text { Silt loam }(20 \% \text { clay, } \\
3.9 \% \text { OM, non- } \\
\text { contaminated }\end{array}$ & 10 & 24 & 2.4 & $\begin{array}{l}\text { DeFlaun \& } \\
\text { Condee } \\
\text { (1997) }\end{array}$ \\
\hline $\begin{array}{l}\text { Sphingomonas } s p \\
\text { L138 }\end{array}$ & EP & $\begin{array}{l}\text { Field-sampled clay } \\
(59 \% \text { clay), non- } \\
\text { contaminated }\end{array}$ & 2 & 11.5 & 5.8 & $\begin{array}{l}\text { Wick et al. } \\
\text { (2004) }\end{array}$ \\
\hline $\begin{array}{l}\text { M. } \\
\text { frederiksbergens } \\
\text { e LB501TG }\end{array}$ & EP & $\begin{array}{l}\text { Field-sampled clay } \\
\text { ( } 59 \% \text { clay), non- } \\
\text { contaminated }\end{array}$ & 2 & 0 & 0 & $\begin{array}{l}\text { Wick et al. } \\
\text { (2004) }\end{array}$ \\
\hline $\begin{array}{l}\text { Sphingomonas sp } \\
\text { L138 }\end{array}$ & EO & $\begin{array}{l}\text { Field-sampled clay } \\
\text { ( } 59 \% \text { clay), non- } \\
\text { contaminated }\end{array}$ & 2 & $0-7.7$ & $0-3.8$ & $\begin{array}{l}\text { Wick et al. } \\
2004\end{array}$ \\
\hline $\begin{array}{l}\text { M. } \\
\text { frederiksbergens } \\
\text { e LB501TG }\end{array}$ & EO & $\begin{array}{l}\text { Field-sampled clay } \\
\text { ( } 59 \% \text { clay }), \text { non- } \\
\text { contaminated }\end{array}$ & 2 & $6.7-13.4$ & $3.4-6.7$ & $\begin{array}{l}\text { Wick et al. } \\
\text { (2004) }\end{array}$ \\
\hline$D h c$ & EO & $\begin{array}{l}\text { Field-sampled clay, } \\
\text { aged contamination }\end{array}$ & 0.8 & 0.3 & 0.4 & $\begin{array}{l}\text { Mao et al. } \\
\text { (2012) }\end{array}$ \\
\hline
\end{tabular}




\begin{tabular}{|c|c|c|c|c|c|c|c|}
\hline \multirow[t]{4}{*}{ EK-ISCO } & Permanganate & EM & $\begin{array}{l}\text { Kaolinitic pottery clay } \\
\text { ( } 28 \% \text { clay), non- } \\
\text { contaminated }\end{array}$ & 1.1 & 1.9 & 1.7 & $\begin{array}{l}\text { Hodges et } \\
\text { al. (2013) }\end{array}$ \\
\hline & Persulfate & EM & $\begin{array}{l}\text { Sand (100\% sand) } \\
\text { non-contaminated }\end{array}$ & 4.0 & 48 & 12 & $\begin{array}{l}\text { Mikkola et } \\
\text { al. (2008) }\end{array}$ \\
\hline & Persulfate & EM & $\begin{array}{l}\text { Silt ( } 100 \% \text { silt }), \text { non- } \\
\text { contaminated }\end{array}$ & 4.0 & 79 & 20 & $\begin{array}{l}\text { Mikkola et } \\
\text { al. (2008) }\end{array}$ \\
\hline & Persulfate & EM & $\begin{array}{l}\text { Fine silt }\left(\mathrm{d}_{50}=45 \mu \mathrm{m}\right) \text {, } \\
\text { Spiked with TCE }\end{array}$ & $0.3-0.5$ & 2 & $4-6$ & $\begin{array}{l}\text { Chowdhury } \\
\text { et al. } \\
\text { (2017a) }\end{array}$ \\
\hline
\end{tabular}

1017

1018

1019

1020

1021

1022

1023
Table 4: Summary of transport velocities for chlorinated ethenes (>85\% removal), lactate, bacteria, permanganate and persulfate in different soils calculated from literature. The velocities are not directly comparable since data available varies between references. The velocities are rather orders of magnitude than exact velocities. $(O M=$ organic matter $)$ 


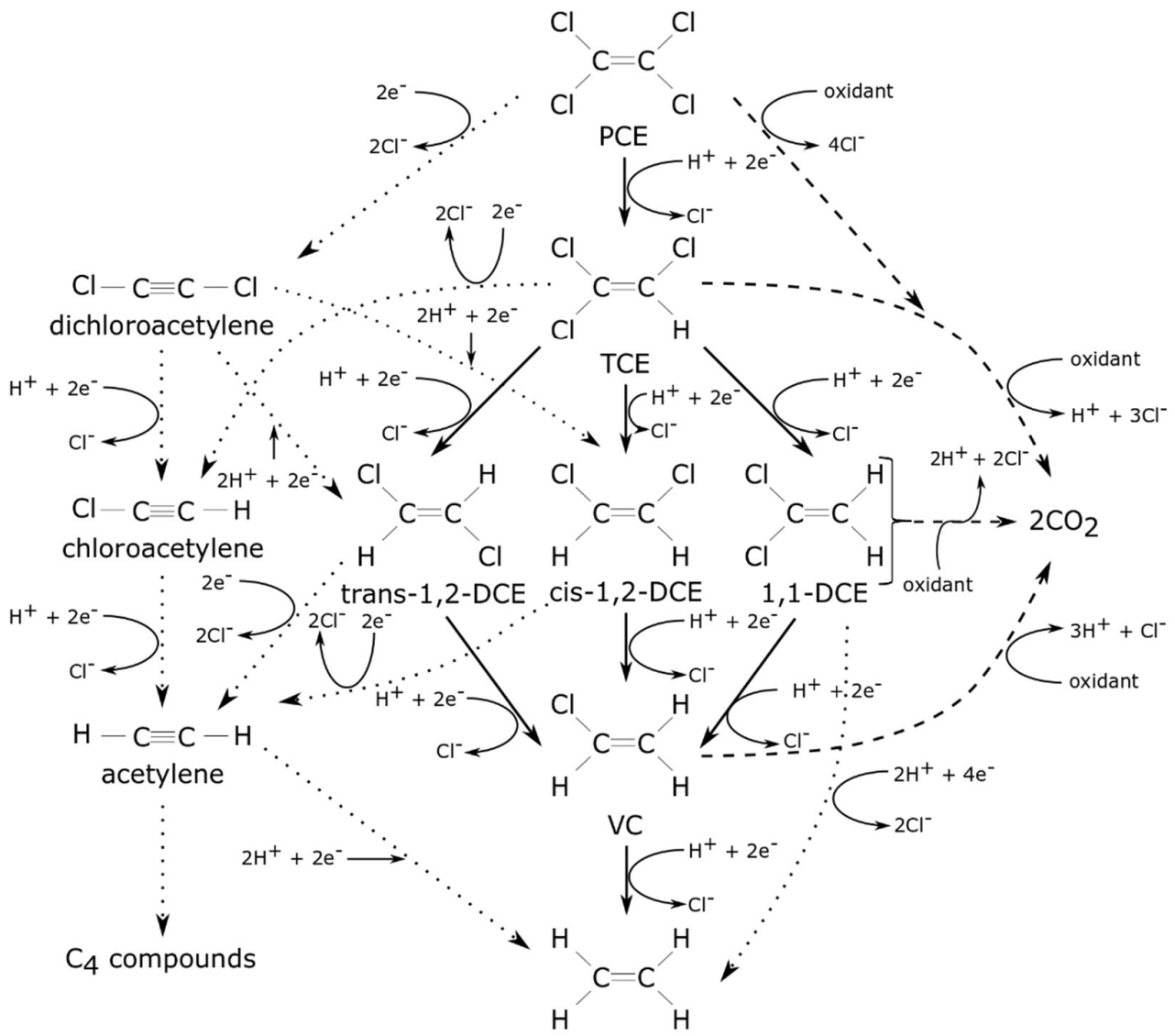

ethylene (ethene)

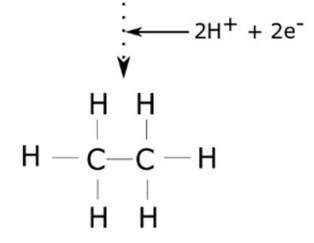

1026

Figure 1. Degradation pathways for the chlorinated ethenes tetrachloroethylene (PCE), trichloroethylene (TCE), 